\title{
Archaeological Testing at Crook's Park in San Marcos, Hays County, Texas
}

Diane A. Cargill

Center for Archaeological Research

Maureen Brown

Center for Archaeological Research

Follow this and additional works at: https://scholarworks.sfasu.edu/ita

Part of the American Material Culture Commons, Archaeological Anthropology Commons, Environmental Studies Commons, Other American Studies Commons, Other Arts and Humanities Commons, Other History of Art, Architecture, and Archaeology Commons, and the United States History Commons

Tell us how this article helped you.

This Article is brought to you for free and open access by the Center for Regional Heritage Research at SFA ScholarWorks. It has been accepted for inclusion in Index of Texas Archaeology: Open Access Gray Literature from the Lone Star State by an authorized editor of SFA ScholarWorks. For more information, please contact cdsscholarworks@sfasu.edu. 


\section{Archaeological Testing at Crook's Park in San Marcos, Hays County, Texas}

Creative Commons License

(c) $)$ (i) @

This work is licensed under a Creative Commons Attribution-NonCommercial 4.0 International License 


\section{Archaeological Testing at Crook's Park in San Marcos, Hays County, Texas}

Diane A. Cargill and Maureen Brown

Robert J. Hard and C. Britt Bousman

Principal Investigators

Texas Antiquities Committee Permit No. 1811

${ }^{\oplus}$ copyright

Center for Archaeological Research

The University of Texas at San Antonio

Archaeological Survey Report, No. 263

1997 
The following information is provided in accordance with the General Rules of Practice and Procedure, Chapter 41.11 (Investigative Reports), Texas Antiquities Committee:

1. Type of Investigation: Testing

2. Project Name: Crook's Park Testing

3. County: Hays

4. Principal Investigators: Robert J. Hard and C. Britt Bousman

5. Name and Location of Sponsoring Agency: City of San Marcos Parks and Recreation Dept., San Marcos, Texas

6. Texas Antiquities Committee Permit No.: 1811

7. Published by The Center for Archaeological Research, The University of Texas at San Antonio, 6900 N. Loop 1604 W., San Antonio, Texas 78249-0658, 1997

A list of publications offered by the Center for Archaeological Research is available. Call (210) 458-4378; write to the Center for Archaeological Research, The University of Texas at San Antonio, 6900 N. Loop 1604 W., San Antonio, Texas 78249-0658; e-mail to car@lonestar.utsa.edu; or visit CAR's Web site at http://www.csbs.utsa.edu/research/car/index.htm. 


\section{Abstract}

Archaeological testing at site 41HY261 was conducted from March 26-31, 1997, by the Center for Archaeological Research (CAR) of The University of Texas at San Antonio, for the city of San Marcos Parks and Recreation Department. Testing demonstrates that $41 \mathrm{HY} 261$ contains deep, intact, stratified subsurface cultural deposits. Collectively, the artifacts recovered to date represent ca. 5,000 years of hunter-and-gatherer activity. Site $41 \mathrm{HY} 261$ has the potential to contribute significantly to the prehistory of the region, and is therefore recommended as eligible for nomination to the National Register of Historic Places. 


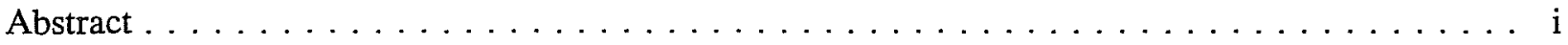

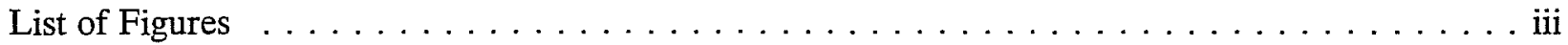

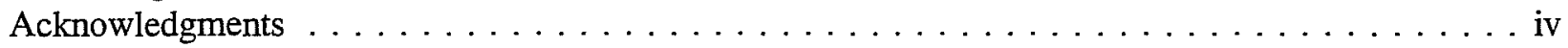

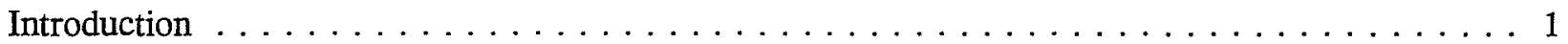

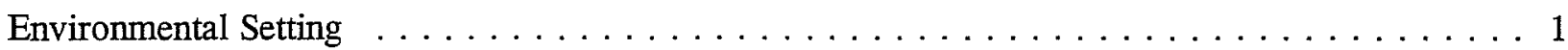

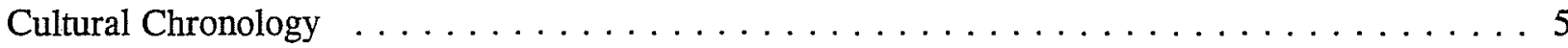

History of Investigations at $41 \mathrm{HY} 261$ and Past and Modern Impacts $\ldots \ldots \ldots \ldots \ldots \ldots$

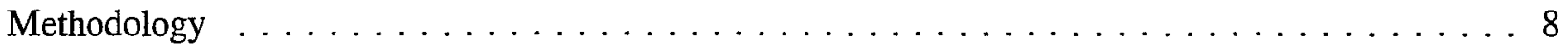

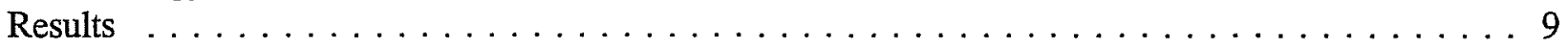

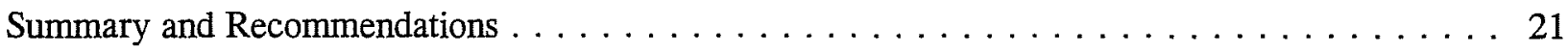

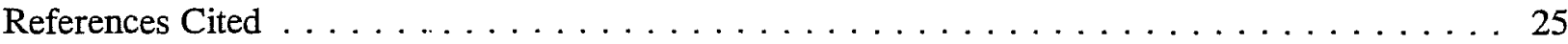

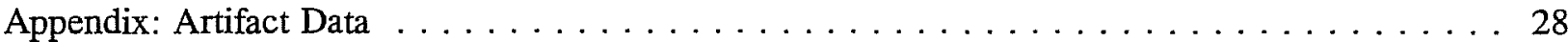




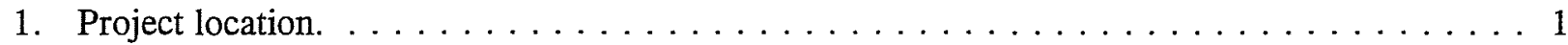

2. Original 1994 site boundaries and modern disturbances. . . . . . . . . . . . . . 2

3. CAR's project area and site boundaries including test units and shovel tests. . . . . . . 3

4. North wall trench profile. . . . . . . . . . . . . . . . . . . 10

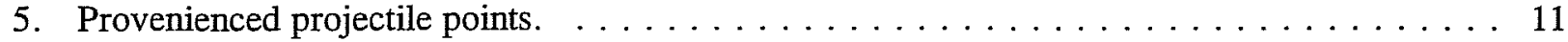

6. Total prehistoric artifact counts by level for STs $1,2,3,4 \mathrm{a}$, and $5 \mathrm{a} . \ldots \ldots \ldots \ldots \ldots \ldots$

7. Total prehistoric artifact counts by level for STs $6,7,9$, and $10 \ldots \ldots \ldots \ldots \ldots \ldots$

8. Total prehistoric artifact counts by level for STs $8,11,12,13,14,15,16,17$, and $18 \ldots \ldots 15$

9. Total prehistoric artifact counts by level for STs $19,20,21,22$, and $23 . \ldots \ldots \ldots \ldots \ldots$

10. Total prehistoric artifact, burned rock, and historic artifact counts by level, TU $1 \ldots \ldots \ldots 18$

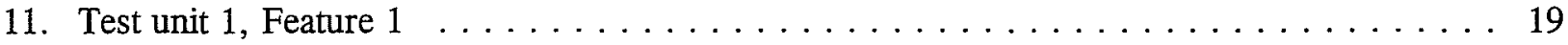

12. Total prehistoric artifact, burned rock, and historic artifact counts by level, TU $21 . \ldots \ldots 20$

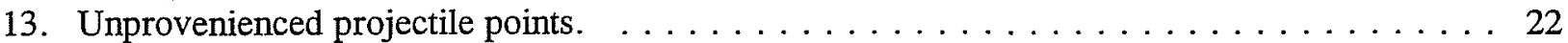

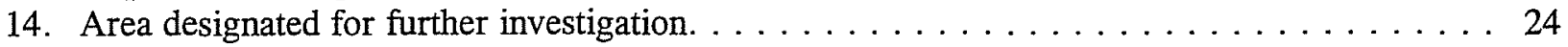




\section{Acknowledgments}

Several people have contributed in various ways to the completion of this project. Thanks goes to Rodney Cobb, William Ford, and Chip Wood (San Marcos Parks and Recreation Department), Kinley Coyan, Mark Denton (Texas Historical Commission), Dr. James Garber (Southwest Texas State University), Jose M. Gill (Gill Engineering), Dr. Thomas R. Hester (Texas Archeological Research Laboratory), and Christopher Ringstaff.

We would like to thank Robert J. Hard and C. Britt Bousman, director and associate director of CAR, for serving as principal investigators. Given the time constraint of the project, special acknowledgment of the field crew is in order. Thanks to Owen Ford, Chris Horrell, Tony Lyle, and Andrew Scease; aided by Ginny Chagnon, Kristi Miller, and Jeff Durst. Bruce Moses and Fernando Londoño, undaunted by the task of compiling and drafting the maps in this report, as well as illustrating the profile and artifacts, deserve special recognition. Thanks also to Britt Bousman for preparing the graphs; and to Marcie Renner and Lucy Vasquez, our technical editors, for their expertise and patience. 


\section{Introduction}

Archaeological testing at site 41HY261 was conducted from March 26-31, 1997, by the Center for Archaeological Research (CAR) of The University of Texas at San Antonio for the city of San Marcos Parks and Recreation Department (Figure 1). Originally recorded in 1994 by S. A. Garza Engineers, 41HY261 was identified as a multi-component historic/prehistoric site on the east bank of the San Marcos River in Hays County, Texas (Figure 2) (McCulloch and Voellinger 1996).

Testing of 41HY261 was required by the Texas Historical Commission as a result of implemented development projects at Crook's Park. In addition, adjacent land recently acquired by the city for park development (Figure 3) necessitated an archaeological survey for the identification of cultural resources. CAR conducted test excava- tions to document and evaluate 41HY261 for eligibility to the National Register of Historic Places and for State Archeological Landmark designation. In compliance with the Texas Antiquities Code, archaeological testing was performed under Texas Antiquities Permit No. 1811. The work was accomplished in 22 person days with a maximum field crew of six and a minimum field crew of two.

\section{Environmental Setting}

The city of San Marcos is located immediately south of the Balcones Escarpment, in the northern Gulf Coastal Plain physiographic region (Black 1989a). Further division of this major physiographic region, based on topographic and biotic associations, places the project area in the geographic region known as the Blackland Prairie (Black 1989a).

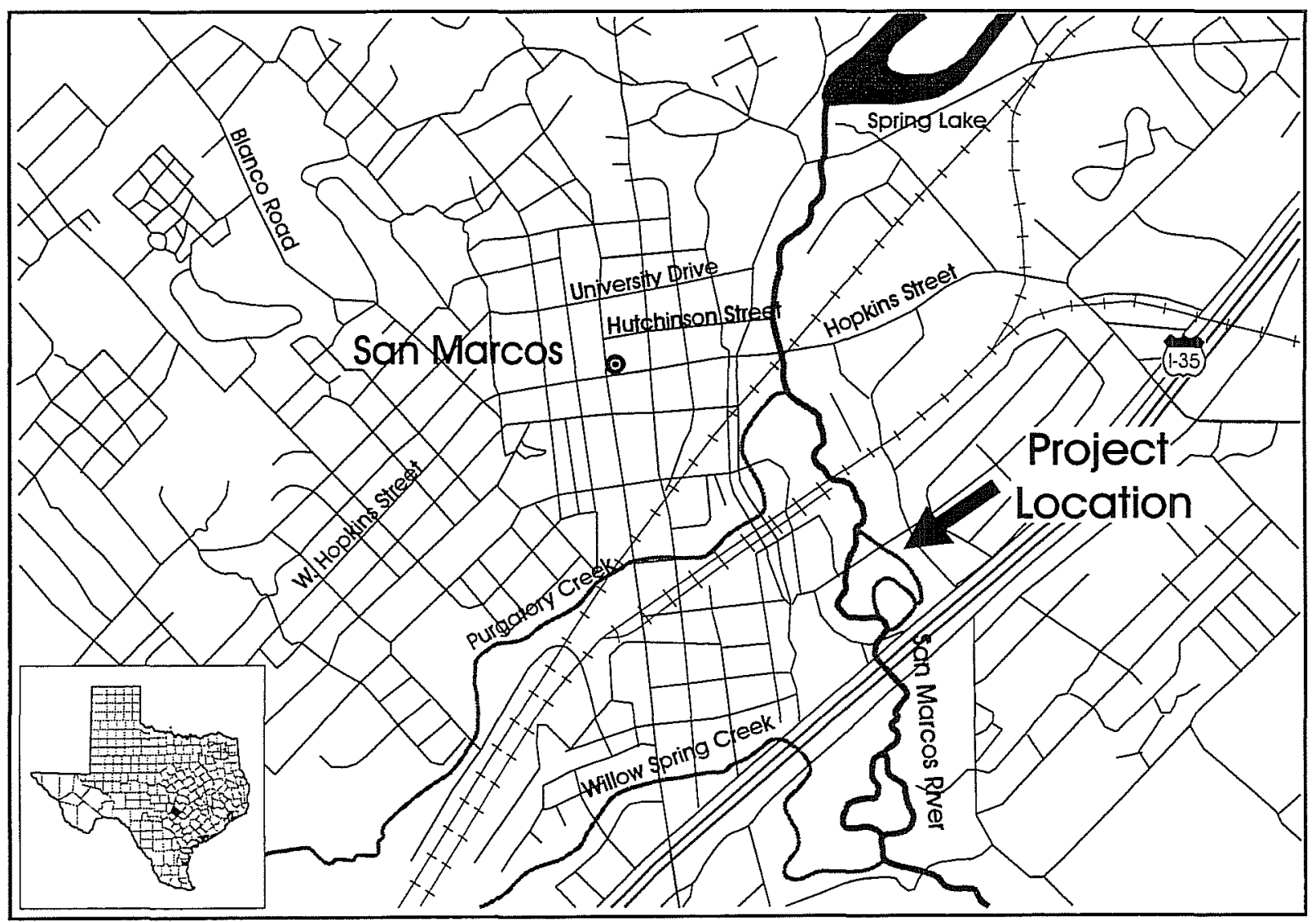

Figure 1. Project location. 
This page has been

redacted because it

contains restricted

information. 
This page has been

redacted because it

contains restricted

information. 
The headwaters of the San Marcos River consist of a series of springs located $1.8 \mathrm{~km}$ north of the project area. The San Marcos River flows southward, joining the Guadalupe River, which eventually empties into the San Antonio Bay and the Gulf of Mexico.

\section{Climate}

The study area lies within a transitional zone between a subtropical, subhumid climatic region of the Edwards Plateau west of San Marcos, and a region of subtropical humid climate to the east (Ricklis and Collins 1994). Characterized by warm to hot summers and dry winters, the mean annual temperature in Austin (approximately $64 \mathrm{~km}$ north of the project area) is $68^{\circ} \mathrm{F}$ (Bomar 1983). Average annual precipitation is between 32 and 36 inches, with high rainfall occurring in May and September and low rainfall reported for January, March, and July.

\section{Geology}

The geology of the project area is mapped as Recent Alluvium by Barnes (1979). These floodplain deposits are comprised of calcareous, dark gray to dark brown clay and silt, quartz sand, and mainly chert, quartzite, and petrified wood gravels. The fluviatile morphology is well preserved as evidenced by point bars, oxbows, and abandoned channel segments (Barnes 1979).

\section{Soil}

The soil of the project area and site 41HY261 is mapped as Oakalla silty clay loam, rarely flooded, and Oakalla silty clay loam, frequently flooded (Batte 1984). The former occur as nearly level soils on smooth slopes on flood plains. These soils are deep and well drained. Surface runoff is slow, permeability moderate, and the rooting zone is deep. Flooding occurs only under abnormal weather conditions. Oakalla silty clay loams, frequently flooded, are deep, nearly level soils on smooth to slightly undulating flood plains. They are comprised of loam, clay loam, silty clay, or silty clay loam, and are moderately alkaline, and calcareous, containing about 60 percent calcium carbonate. This soil is flooded briefly, often more than once every two years, and permeability is moderate.

\section{Flora}

The study area lies within the Blackland Prairie vegetational area which is characterized by a mix of tall grass species (Ricklis and Collins 1994). These include little bluestem (Schizachyrium scoparium), big bluestem (Andropogon gerardi), Indiangrass (Sorghastrum avenaceum), switch grass (Panicum virgatum), sideoats grama (Bouteloua curtipendula), and hairy grama (Bouteloua hirsuta) (McCulloch and Voellinger 1996). Oak mottes are typically found in the upland areas, and larger stream riparian zones contain oak, pecan, walnut, hackberry, sumac, bald cypress, and cottonwood trees. Mesquite is common to higher stream terraces, but is also present in the deep soils of gentle upland slopes (Ricklis and Collins 1994).

\section{Fauna}

The Blackland Prairie vegetational area is included in the Texan biotic province defined by Blair (1950). Blair identifies 49 species of mammals, 2 land turtles, 16 lizards, 39 snakes, and 23 amphibians within this province. In respect to the immediate project area, three federally listed endangered species are present in the San Marcos River and riparian environment. These include the San Marcos salamander (Eurycea nana), the fountain darter (Etheostoma fonticola), and the San Marcos gambusia (Gambusia georgei) (McCulloch and Voellinger 1996). 


\section{Project Area}

The project area is located in urban San Marcos near IH-35. Numerous businesses are present immediately east of Riverside Drive, and a restaurant and associated parking lot are located north of Cheatham Street. A city park and the San Marcos River, both west and north of the site, provide a recreational area for San Marcos residents. Given the extensive use of the immediate area, it is not surprising that the site has been, and continues to be, impacted by various activities, including looting.

\section{Cultural Chronology}

\section{Paleoindian}

The Paleoindian period in Central Texas spans approximately 3,000 years from $11,500-8800$ B.P. (Collins 1995). Two subperiods-Early Paleoindian $(11,500-10,000$ B.P.) and Late Paleoindian $(10,000-8800 \quad$ B.P. $)$-have been identified. Lanceolate projectile points associated with the early subperiod are Clovis, Folsom, and Plainview. Those of the late subperiod include Golondrina, Angostura, Scottsbluff, and Meserve (Black 1989b). Artifacts from the Paleoindian period are commonly found on the surface as isolated finds; however, camp, quarry/stoneworking, kill, cache, ritual, and burial sites have been reported (Collins 1995).

Early Paleoindians have typically been described in the archaeological literature as nomadic, specialized "big game" hunters in pursuit of nowextinct Late Pleistocene fauna such as mammoth and Bison antiquus. With the extinction of these species, a specialized hunting strategy continued through the Late Paleoindian period, but the target of prey shifted to other large herbivores such as Bison bison and deer (Odocoileus). As more data on early Paleoindian subsistence is recovered, however, the perception of "big game" hunters is giving way to "well adapted, generalized huntersgatherers with the technology to hunt big game but not the need to rely exclusively on it" (Collins 1995:382).

\section{Archaic}

The Archaic period in Central Texas spans approximately 7,500 years from $8800-1200$ or 1300 B.P. (Collins 1995). Three subperiodsEarly Archaic (8800-6000 B.P.), Middle Archaic (6000-4000 B.P.) and Late Archaic (4000-1200 or 1300 B.P.)-have been identified. Changes in projectile point styles, a more localized geographic distribution of artifacts, an increase in the number of sites, and the presence of burned rock scatters, hearths, and middens serve to separate the Archaic from the Paleoindian period (Collins 1995).

\section{Early Archaic}

The Early Archaic period is characterized by Gower, Hoxie, Wells, Bell, Andice, Uvalde, Martindale, Baird, and Taylor (Early Triangular) projectile points (Collins and Ricklis 1994). Additional diagnostic artifacts from this subperiod include unifacial and bifacial Clear Fork tools, and the bifacial Guadalupe tool (Black 1989b; Collins 1995). While Early Archaic tools are found beyond Central Texas, implying "broad settlement patterns and resource utilization" (Trierweiler et al. 1995:31), a concentration of early Archaic components located close to the eastern and southern border of the Edwards Plateau along the Balcones Escarpment has been documented (Black 1989b; Collins 1995). One explanation for this apparent pattern focuses on the availability of water along the escarpment during an arid climatic interval (Black 1989b, McKinney 1981). Recovered subsistence remains demonstrate the exploitation of deer, small mammals, reptiles, amphibians, and fish. The intensified use of plant resources is indicated by the presence of cammus bulbs from earth ovens (Collins 1995). Early Archaic hunters and gatherers are considered to have been organized into small, highly mobile bands, with low population densities (Weir 1976). 


\section{Middle Archaic}

The Middle Archaic is characterized by Nolan, Travis, Bulverde, Pedernales, Marshall, Williams, and Lange stemmed projectile points (Collins and Ricklis 1994). In comparison to the Early Archaic, the Middle Archaic is represented by increases in the number of sites, site size, and number of diagnostic artifact types (Collins and Ricklis 1994). Weir (1976) proposes that the observed increase in site density during this period was a direct result of increased population density.

Burned rock features including scatters, hearths, and middens are hallmarks of the Middle Archaic period in Central Texas (Collins 1995). The number of burned rock middens increases, and the maximum size and thickness of these features are reached during this period (Collins and Ricklis 1994). Several ideas regarding the function of burned rock middens have been offered; however, it is commonly accepted that their presence is directly linked to food processing. Subsistence remains recovered from burned rock middens include deer, acorns, and charred bulbs.

\section{Late Archaic}

The Late Archaic is characterized by Marcos, Castroville, Montell, Ensor, Frio, Fairland, and Darl points (Collins and Ricklis 1994). The number of sites and components reaches an all time high in the Late Archaic period of Central Texas prehistory (Trierweiler et al. 1995). If site density is an accurate indicator of population density, it appears that the prehistoric population of Central Texas peaked at this time (Trierweiler et al. 1995). For the first time in the prehistory of Central Texas, cemetery sites became part of the archaeological inventory of site types. Relatively large trade networks are indicated by the presence of marine shell in cemeteries, and corner tang knives have been recovered throughout Texas and beyond (Trierweiler et al. 1995). As for burned rock, "accumulating evidence supports continued and possibly increased use, throughout the Late Archaic" (Trierweiler et al. 1995:33).

\section{Late Prehistoric Period}

The Late Prehistoric period in Central Texas spans approximately 800 years from $1150-350$ B.P. (Black 1989b). Two phases identified within this period are the Austin (1150-650 B.P.) and the Toyah (A.D. $650-350$ B.P.). The Late Prehistoric period is characterized by changes in point style and ceramic manufacture (Trierweiler et al. 1995). The presence of small arrow points (Edwards, Scallorn, and Perdiz) indicates a change to bow-and-arrow technology (Collins 1995).

The Austin phase is considered to be a continuation of the Late Archaic adaptation with an equal emphasis on both hunting and gathering (Collins and Ricklis 1994). Similarly, cemeteries containing marine shell artifacts remain in use during this time.

Based on the presence of bison remains and a tool assemblage comprised of Perdiz arrow points, large unifacial end scrapers, and beveled bifacial knives, Toyah phase sites reflect a shift in the exploitation of resources (Collins and Ricklis 1994). This tool assemblage is believed to be associated with the hunting and processing of bison. However, Toyah phase components such as the Mustang Branch site on Onion Creek (Ricklis 1994) and the Panther Springs and Hinojosa sites of South Texas demonstrate the continued importance of deer (Black 1989c). The manufacture of ceramics occurs sometime after A.D. 1300 (Trierweiler et al.1995). Recent data indicate that burned rock midden technology was still in use during the Late Prehistoric period (Black et al. 1996; Tennis 1996; Trierweiler et al. 1995).

\section{Historic Period}

European presence in Central Texas may have occurred as early as the mid-sixteenth century when the de Soto expedition traveled from northeast Texas, southwestward along the Balcones Escarpment as far as the New Braunfels 
area (Bruseth 1992). It was not until 1684, however, that the northern frontier of Tejas became an important consideration for Spain, brought about by French presence in East Texas (Bannon 1979). Subsequently, several Spanish missions were constructed in the late-seventeenth and early to mid-eighteenth centuries in east, central, and south Texas.

In addition to various factors of change induced by French and Spanish colonization efforts, the horse and European disease are cited as two important causes of the biological and social disruption of Native American groups indigenous to Texas (Collins and Ricklis 1994). By the midto late-nineteenth century, "the more than 11 millennia of Native American presence in the area came to an end" (Collins 1995:387).

\section{History of Investigations at 41HY261 and Past and Modern Impacts}

Site 41HY261 was recorded in 1994 by S. A. Garza Engineers during a cultural resource survey for the city of San Marcos Parks and Recreation Department (McCulloch and Voellinger 1996). A four-acre tract of land (referred to as the Henry Tract) east of the San Marcos River, and both north and south of Cheatham Street (Figure 2), was investigated by a 100-percent-pedestrian survey, archival research, and oral interviews (McCulloch and Voellinger 1996). Site 41HY261 is described as multi-component, containing cultural material representative of both the historic and prehistoric periods. The historic component is comprised of a dam, millrace, and mill or pump house, located along and adjacent to the upper terrace. The prehistoric component is described as an open campsite located on the upper terrace (McCulloch and Voellinger 1996). Lithic material in the form of cores, flakes, and debitage was observed on the ground surface. A biface fragment, numerous flakes, and animal bone fragments were recovered from shovel tests dug to a depth of $60 \mathrm{~cm}$ below the surface ( $\mathrm{cm} \mathrm{bs}$ ). The depth of cultural material at this site was not determined as shovel tests were terminated at
$60 \mathrm{~cm}$ bs (McCulloch and Voellinger 1996). In addition, flakes and debitage were observed in the backdirt of several looters' holes. The temporal affiliation of the prehistoric component was reported to be unknown due to the absence of diagnostic tools.

Numerous activities have impacted site 41HY261. North of Cheatham Street, McCulloch and Voellinger (1996) report an asphalt parking lot and lawn; and south of Cheatham Street, several structures associated with a recreational water facility are still present. At the corner of Riverside Drive and the IH-35 frontage road, a greenhouse/ nursery structure remains. Additional impacts to the site include sidewalks, a bridge crossing over the millrace, and other possible structures as well. Approximately 10 looters' holes, some as much as one meter deep and one meter in diameter, were reported. Recent bike trails constructed and banked with soil derived from looters' backdirt were observed (McCulloch and Voellinger 1996). The banks along the San Marcos River north of Cheatham Street have been modified by public recreation of the river. Site $41 \mathrm{HY} 261$ was recommended for further testing if future construction would alter subsurface deposits (McCulloch and Voellinger 1996).

In the fall of 1995, Chris Ringstaff, a graduate student from the Geography Department at Southwest Texas State University, mapped the location and dimensions of 11 looters' pits at 41HY261 (Figure 2). Ringstaff (personal communication 1997) also noted that areas of the site had been disturbed by the local youth in their attempt to construct bike jumps, and that artifacts were present in these areas of disturbance. This map was presented to the San Marcos Parks and Recreation Department to help curb ongoing looting activity at the site.

In January 1997, the city of San Marcos constructed a parking lot without conducting archaeological investigations. Parking lot construction at $41 \mathrm{HY} 261$ resulted in varying depths of subsurface disturbance (Figure 2). In general, disturbance is deepest $(120 \mathrm{~cm}$ deep) in the northwest quadrant of the parking lot and 
shallowest (30-50 cm deep) as one moves south and east toward Riverside Drive. Ten to $20 \mathrm{~cm}$ of subsurface deposits were disturbed by the construction of a restroom facility located just north of the parking lot. In addition, the site has been impacted by a 19-m-long by one-meter-deep backhoe trench excavated to provide a drainage system for the parking lot.

Archaeological investigation of the newly acquired land south of $41 \mathrm{HY} 261$ had not been conducted prior to the present testing by CAR (Figure 2). Foundation slabs/pads of a past trailer park near IH-35 were removed by the city of San Marcos, and four structure foundation slabs were left. Trees and vegetation along and near the edge of the upper terrace were removed for the construction of a walking/biking trail. Twenty light posts were installed throughout the park, and trenches for electrical wiring, approximately 50 $\mathrm{cm}$ wide and $50 \mathrm{~cm}$ deep, connecting the light posts were excavated. In some areas grading/ blading and filling has occurred. The material used to fill in "low spots" of the park was derived from site 41HY261 during the construction of the parking lot (Figure 2). Therefore, these relatively large fill areas contain displaced artifacts in approximately the upper $20 \mathrm{~cm}$ of soil.

\section{Methodology}

\section{Field Methods}

In order to document the horizontal extent of subsurface deposits and to evaluate the site for significance eligibility, two test units (TUs) and 23 shovel tests (STs) were excavated. Test units were placed within the 1994 established site boundary, and shovel tests were randomly located in both the site area and the newly acquired land south of 41HY261 (Figure 3). Three shovel tests were intentionally placed in "fill areas" to document displaced artifacts originating from the construction of the parking lot, and to differentiate these "fill artifacts" from underlying legitimate site deposits. In determining the placement of test units and shovel tests, Ringstaff's map was consulted to avoid areas of past looting activity. In addition, a profile of the north wall of an existing backhoe trench excavated by the city of San Marcos was drawn.

Two $1-\mathrm{x}-1-\mathrm{m}$ test units were excavated in 10-cm arbitrary levels using trowels, sharpshooters, and a pickaxe. TU 1 was excavated to a depth of 50 $\mathrm{cm}$ bs and TU 2 was dug to a depth of $150 \mathrm{~cm}$ bs. Twenty-three shovel tests, approximately $30 \times 30$ $\mathrm{cm}$ in plan view, were excavated in $10-\mathrm{cm}$ arbitrary levels using sharpshooters and trowels. Eighteen of the 23 shovel tests were dug to a minimum depth of $50 \mathrm{~cm}$ bs and a maximum depth of $70 \mathrm{~cm} \mathrm{bs}$. Four of the 23 shovel tests warranted special consideration due to their location adjacent to the parking lot. ST 23 was dug to a depth of $20 \mathrm{~cm}$ bs, and STs 19,20 , and 22 were each excavated to $40 \mathrm{~cm}$ bs. ST 18 encountered construction gravels at $40 \mathrm{~cm}$ bs and was therefore terminated. Soil from the test units and shovel tests was screened through $1 / 4$-inch wire mesh.

Artifacts were inventoried in the field, assigned lot numbers, and transported to the CAR laboratory. Modern cultural material was noted on standard CAR shovel test and test unit level forms but not collected. If an object could not positively be identified as historic or modern, it was collected. Careful attention was paid to note surface and subsurface disturbance in each shovel test and test unit. Soil color and texture, mottling, and the presence of modern, historic, and prehistoric artifacts were carefully recorded for each level. Photographs using print and slide film were taken and recorded on standard CAR photo log forms. Maps produced for this report are a composite of data provided by CAR, Gil Engineering Associates Inc., and Christopher Ringstaff.

\section{Laboratory Methods}

Artifacts recovered from the surface, test units, and shovel tests were transported to the CAR laboratory for washing, labeling, analysis, and curation. Artifacts were sorted, counted, and analyzed according to type as listed in the 
Appendix. Prehistoric artifacts include chert debitage (divided into platform and non-platform flakes), cores, tools (including unifaces, bifaces, projectile points, and ground stones), faunal remains (bone and shell), and burned rock. Historic artifacts include ceramic, glass, and metal. The artifact data were entered into an Excel software spreadsheet and graphs were produced to illustrate horizontal and vertical patterns in the data and facilitate discussion of the results.

\section{Results}

\section{Backhoe Trench}

A profile was drawn of $13.9 \mathrm{~m}$ of the north wall of the city's east-west backhoe trench (Figure 4). $\mathrm{A}$ and $\mathrm{B}$ soil horizons, a transitional $\mathrm{AB}$ horizon, and three disturbed AP zones (AP1, AP2, and AP3) were recorded. AP1 contained surface fill material which included a dark brown silty sediment mixed with gravel. AP2 consisted of a caliche gravel fill zone, and AP3 is comprised of the dark gray silty clay loam of the A horizon with prehistoric and historic artifacts located at the base of this pit-like feature (Figure 4). Below the AP1 and AP2 zones, the intact portion of the A horizon includes a very dark gray silty clay loam with tree roots and some cultural material. The transitional mottled $A B$ horizon near the eastern end of the profile begins at approximately $40 \mathrm{~cm}$ bs and extends to a depth of about $80 \mathrm{~cm}$ bs. The beginning depth of the $\mathrm{B}$ horizon varies across the trench profile and is observed between 40 and 80 $\mathrm{cm}$ bs. The $\mathrm{B}$ horizon consists of a yellowish-red fine silty clay with tree roots. Within the B horizon, two lenses are noted. One includes a sand mottled inclusion, and the other is a charcoal lens which also contains burned rock. The recent AP3 disturbance appears to truncate the west side of the transitional $\mathrm{AB}$ horizon and also appears to have been excavated into the $B$ horizon west of the ash lens. The disturbance (AP3) is located approximately $8.5-11.5 \mathrm{~m}$ from the western end of the trench. At the bottom of the disturbance is an ash lens with prehistoric and historic artifacts
(Figure 4). Geological deposits appear to be less disturbed in the western half of the profile.

Cultural material occurs in two distinct zones throughout the trench. In addition, material was associated with two distinct lenses: the ash lens located within the disturbed area (AP3), and the charcoal lens located within the B horizon. From the surface to 20 or $30 \mathrm{~cm}$ bs within the A horizon, the profile contained a consistent, but mixed assemblage of prehistoric artifacts (i.e., debitage, burned rock, and snail shell fragments) and historic and modern artifacts (i.e., glass and metal). At the top of the $B$ horizon is a zone containing a scatter of Rabdotus shell fragments and a few prehistoric debitage fragments. Further west in the trench, a charcoal lens was located from $60-80 \mathrm{~cm}$ bs just below the Rabdotus shell fragment zone in the B horizon. A few burned limestone cobbles were located at the same level. The disturbed area (AP3) included an ash lens with cultural material. A Middle Archaic period Pedernales proximal base fragment (Figure 5a) and two brown beer glass bottle fragments were included in the assemblage associated with the ash lens in the disturbed area designated as AP3.

\section{Shovel Tests}

Shovel Tests $1-5 a$

Seven shovel tests (STs 1, 2, 3, 4, 4a, 5, and 5a) were excavated north of the city's east-west backhoe trench and west of the newly constructed restroom facility (Figure 3). ST 4 was abandoned immediately due to waste contam-ination from an adjacent portable restroom. ST 5 was abandoned after excavation of Level 1 because we decided to increase the spacing between shovel tests. Shovel tests were excavated to a depth of $60 \mathrm{~cm}$ bs in 10$\mathrm{cm}$ levels. Each test was excavated into the gravel fill material, through the A horizon, and partially into the top of the $B$ horizon.

All five shovel tests contained modern debris and historic material from the surface to a minimum of 


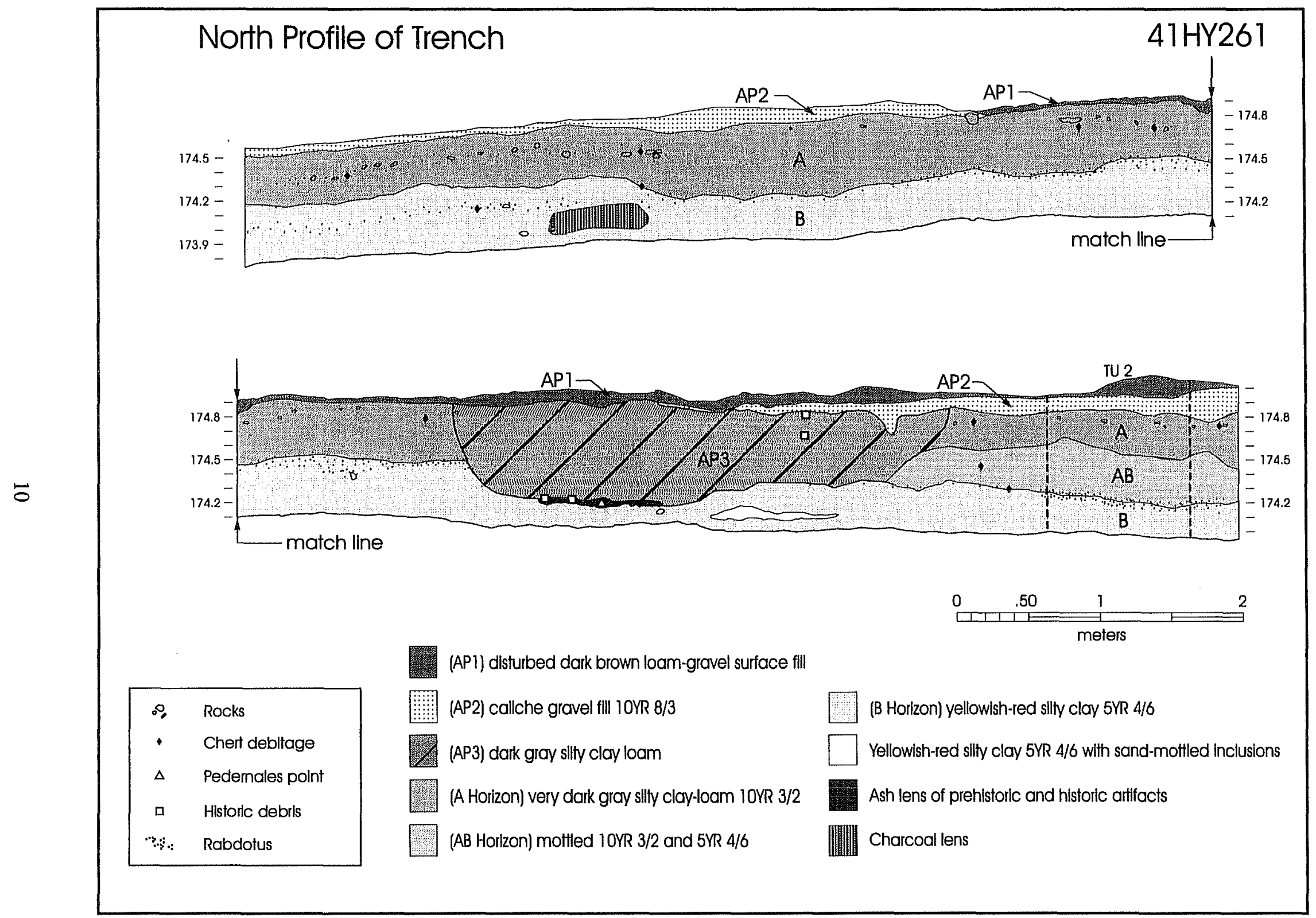

Figure 4. North wall trench profile. 


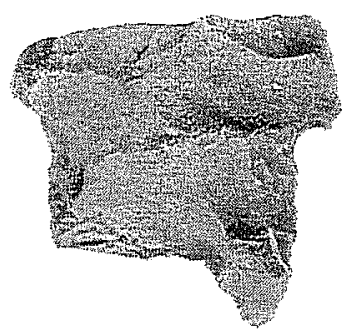

a

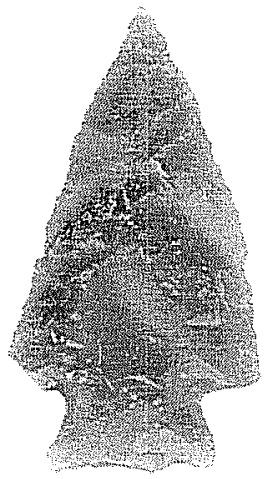

e

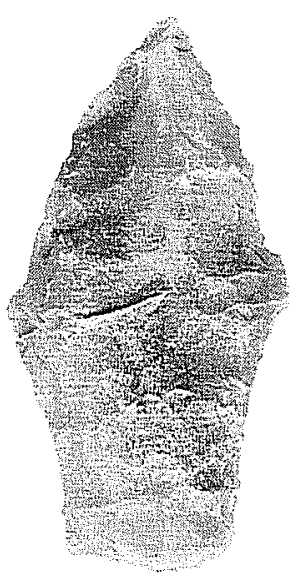

b

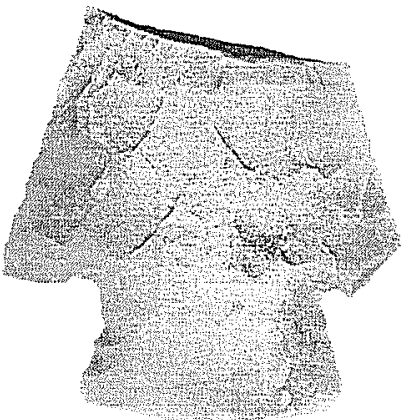

f

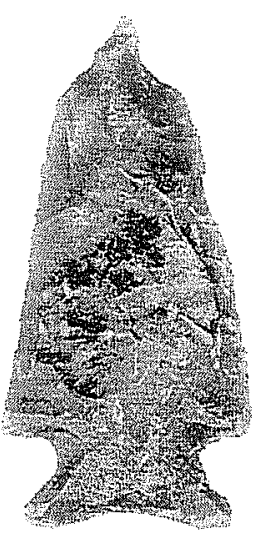

C

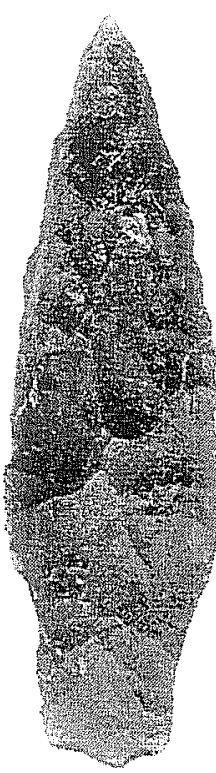

d

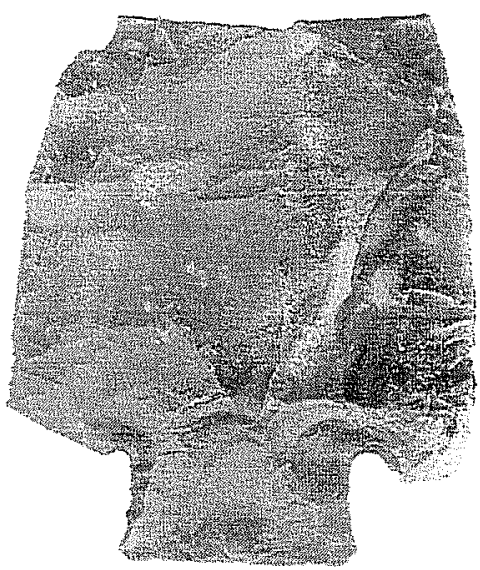

g

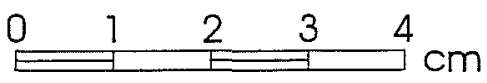

Figure 5. Provenienced projectile points. a. Pedernales; b. unidentifiable; c. Fairland; d. unidentifiable; e. Ensor; f. Castroville; and g. Marshall.

$10 \mathrm{~cm}$ bs within the surface fill and A horizon. Prehistoric artifacts were present in all seven of the shovel tests (Appendix and Figure 6). The tests also contained late-nineteenth- through early twentieth-century historic remains. ST 1 yielded numerous pieces of prehistoric debitage, especially non-platform flakes, between 20 and 40 $\mathrm{cm}$ bs within the A horizon. Several pieces of burned rock were found at the same levels. However, STs 1 and 2 were mixed; they contained an assemblage of modern and historic materials with prehistoric remains from the 


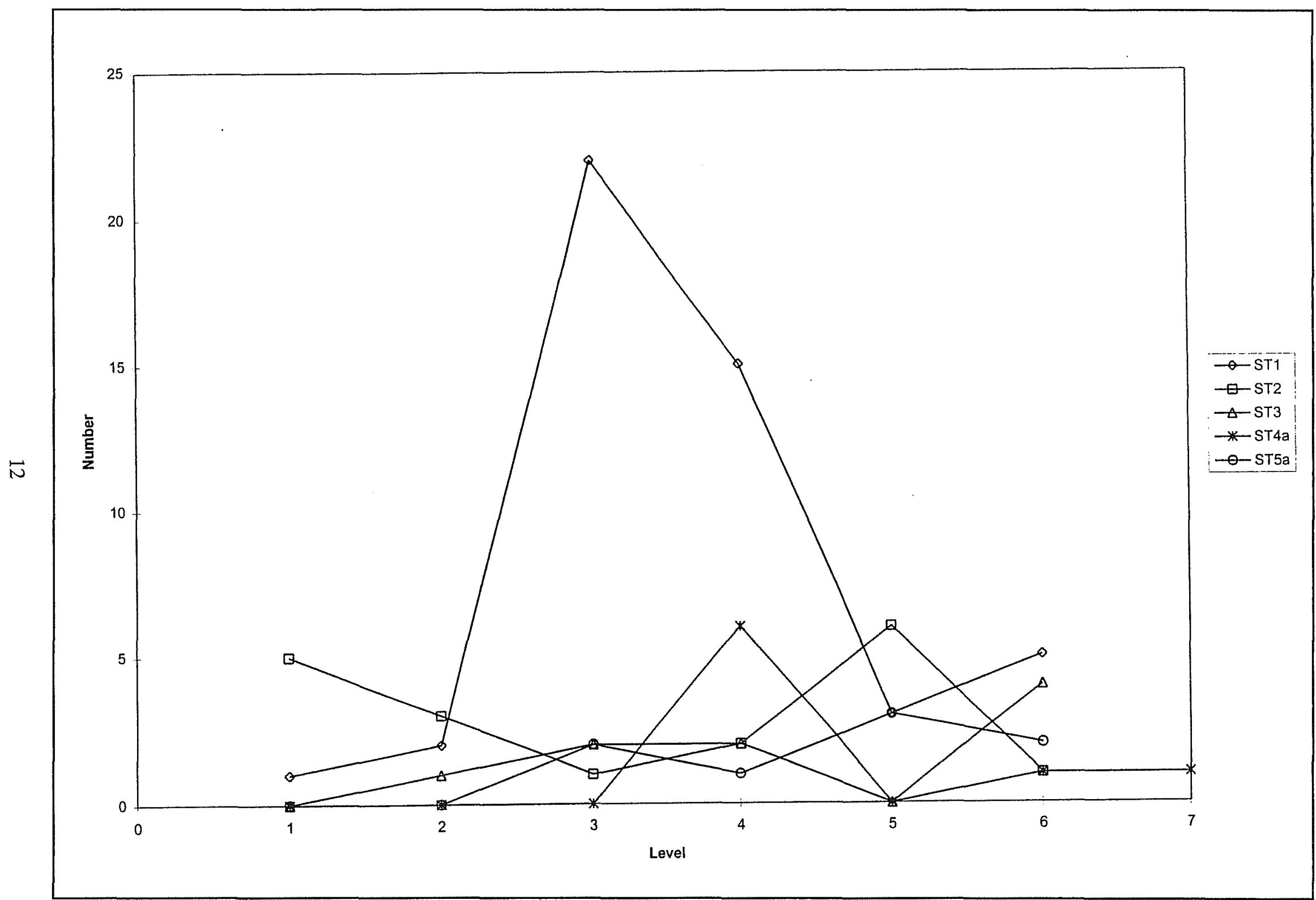

Figure 6. Total prehistoric artifact counts by level for STs 1, 2, 3, 4a, and 5 a. 
surface to $60 \mathrm{~cm}$ bs. STs 3 and 4a yielded modern materials within the upper $30 \mathrm{~cm}$ bs and prehistoric remains from $30-60 \mathrm{~cm}$ bs. ST $5 \mathrm{a}$ contained historic materials only within the top 10 $\mathrm{cm}$ bs. A cobalt-colored glass bead was recovered from this level. ST 5a yielded intact, undisturbed geological deposits and archaeological remains from $10-60 \mathrm{~cm}$ bs.

Shovel Tests $6,7,9$, and 10

Four shovel tests (STs 6, 7, 9, and 10) were excavated south of the city's backhoe trench and west of the parking lot (Figure 3), near the area of the looters' holes, and along the edge of the terrace escarpment. STs 6 and 7 were excavated to a depth of $60 \mathrm{~cm} \mathrm{bs}$, and STs 9 and 10 were excavated to $50 \mathrm{~cm}$. All contained A and B soil horizons. Modern debris and historic artifacts were present in ST 6 to $20 \mathrm{~cm}$ bs, ST 7 to $50 \mathrm{~cm}$ bs, and ST 10 to $30 \mathrm{~cm}$ bs. No historic or modern debris was found in ST 9. Prehistoric artifacts were present in the four shovel tests at every level beginning just beneath the surface, but increasing in numbers between 20 and $40 \mathrm{~cm}$ (Appendix and Figure 7). Burned rock, including burned caliche, in ST 6 and Rabdotus shell fragments in ST 10 were present in these levels as well. Within ST 7, an unidentifiable, heavily reworked complete projectile point was recovered at $5 \mathrm{~cm}$ bs (Figure 5b). Artifact numbers decrease between 40 and 50 $\mathrm{cm}$ bs; however, ST 7 clearly shows an increase in numbers of prehistoric artifacts between 50 and $60 \mathrm{~cm}$.

\section{Shovel Tests 8 and 11-18}

Nine shovel tests, numbered STs 8 and 11-18, were placed randomly throughout fill and non-fill areas where existing and pre-existing concrete trailer park slabs were located. This area is adjacent to Riverside Drive, the $\mathrm{IH}-35$ access road, and the greenhouse (Figure 3). These shovel tests were excavated to a depth of $50 \mathrm{~cm}$ bs, except ST 18 which yielded road gravel at $40 \mathrm{~cm}$ bs and was therefore terminated early. Three shovel tests $(14,15$, and 18) were placed in "fill areas" in order to document displaced artifacts originating from that part of the site (parking lot) which was used as fill material. Shovel test 18 showed a consistent dark brown clay loam with reddish mottles from the surface to $40 \mathrm{~cm}$ bs (road gravel was encountered at $40 \mathrm{~cm} \mathrm{bs}$ ).

Within the upper levels of STs 14 and 15, a dark grey clay loam matrix mixed with yellowish red clay loam and gravels (a mixture of A and B horizons) was observed. A dark gray clay loam with less mixing was observed between 20 and 25 $\mathrm{cm}$ bs and a homogenous dark gray clay loam from 25 to $50 \mathrm{~cm}$ bs. In addition, intact grass sod was observed within ST 15 at a depth of $20 \mathrm{~cm}$ bs. Outside the fill areas, ST 16 contained the reverse: a dark grey clay loam layer (A horizon) was observed in the first $25 \mathrm{~cm}$, and mixing of the yellowish red clay matrix (B horizon) was observed to a depth of $50 \mathrm{~cm}$ bs. STs 11,12 , and 13 contained an upper caliche gravel layer to about $25 \mathrm{~cm}$ bs, and directly beneath the caliche gravel, a dark grey clay loam with gravel (A horizon) was present to a depth of $50 \mathrm{~cm}$ bs. Shovel test 17 was similar to STs 14 and 15 , and a modern concrete layer was encountered at 50 $\mathrm{cm}$ bs in ST 8.

All but two (STs 12 and 13) of the nine shovel tests yielded prehistoric artifacts (Appendix and Figure 8). A Late Archaic period Fairland projectile point (Turner and Hester 1993:117) was found on the surface near ST 18. The distal end of the point appears to have been reworked into a drill (Figure 5c). Shovel tests $(14,15$, and 18) placed within the fill areas exhibited mixed horizon matrix. Shovel tests 14 and 18 also contained gravels which may have been laid prior to the construction of the trailer park concrete slabs or road fill. STs 11 and 15 contained undisturbed prehistoric material beneath the upper disturbed levels. STs 8 and 18 were disturbed throughout all levels, and ST 16 yielded the only geologically and archaeologically intact deposits. 


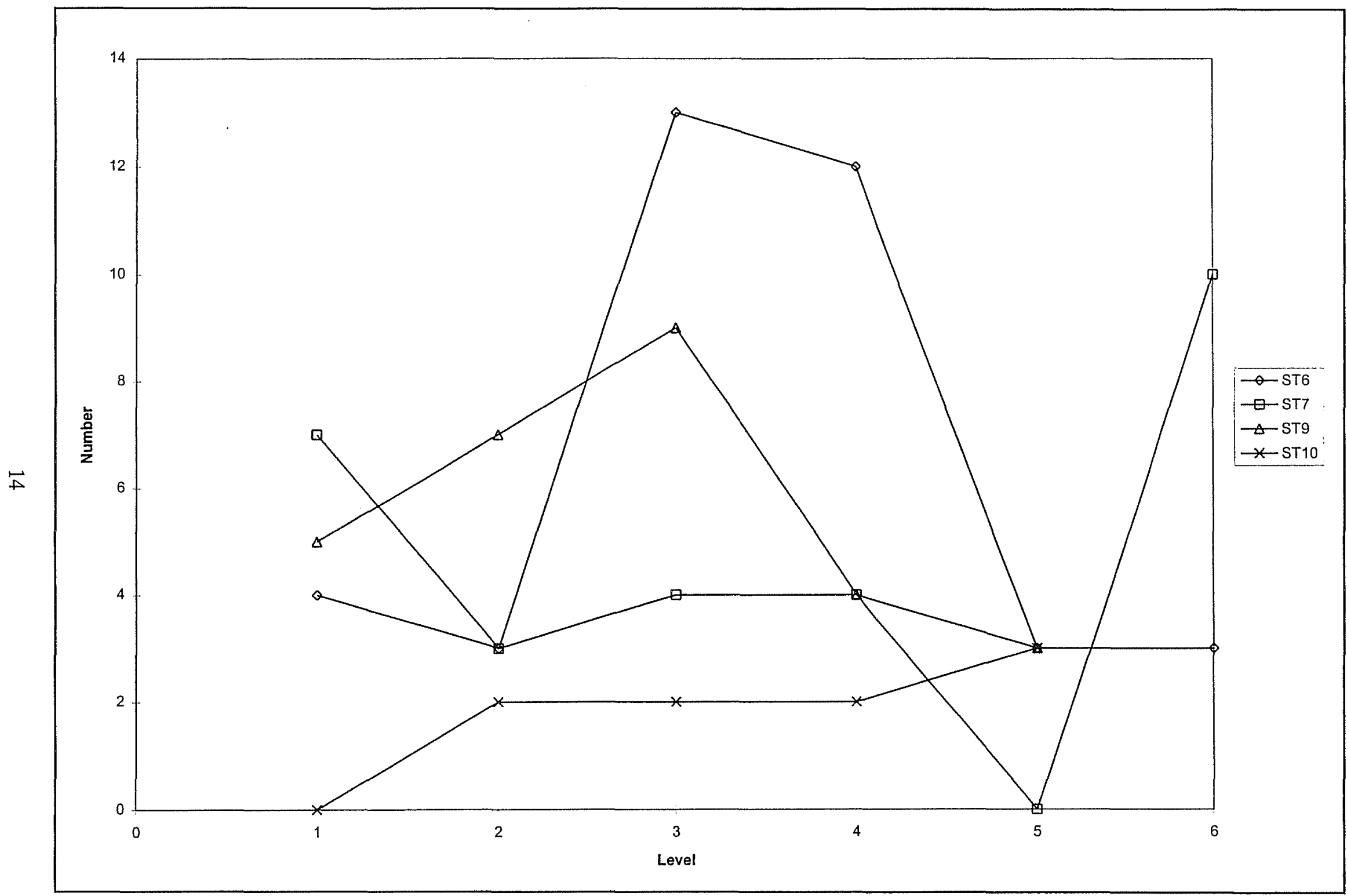

Figure 7. Total prehistoric artifact counts by level for ITs 6, 7, 9, and 10 . 


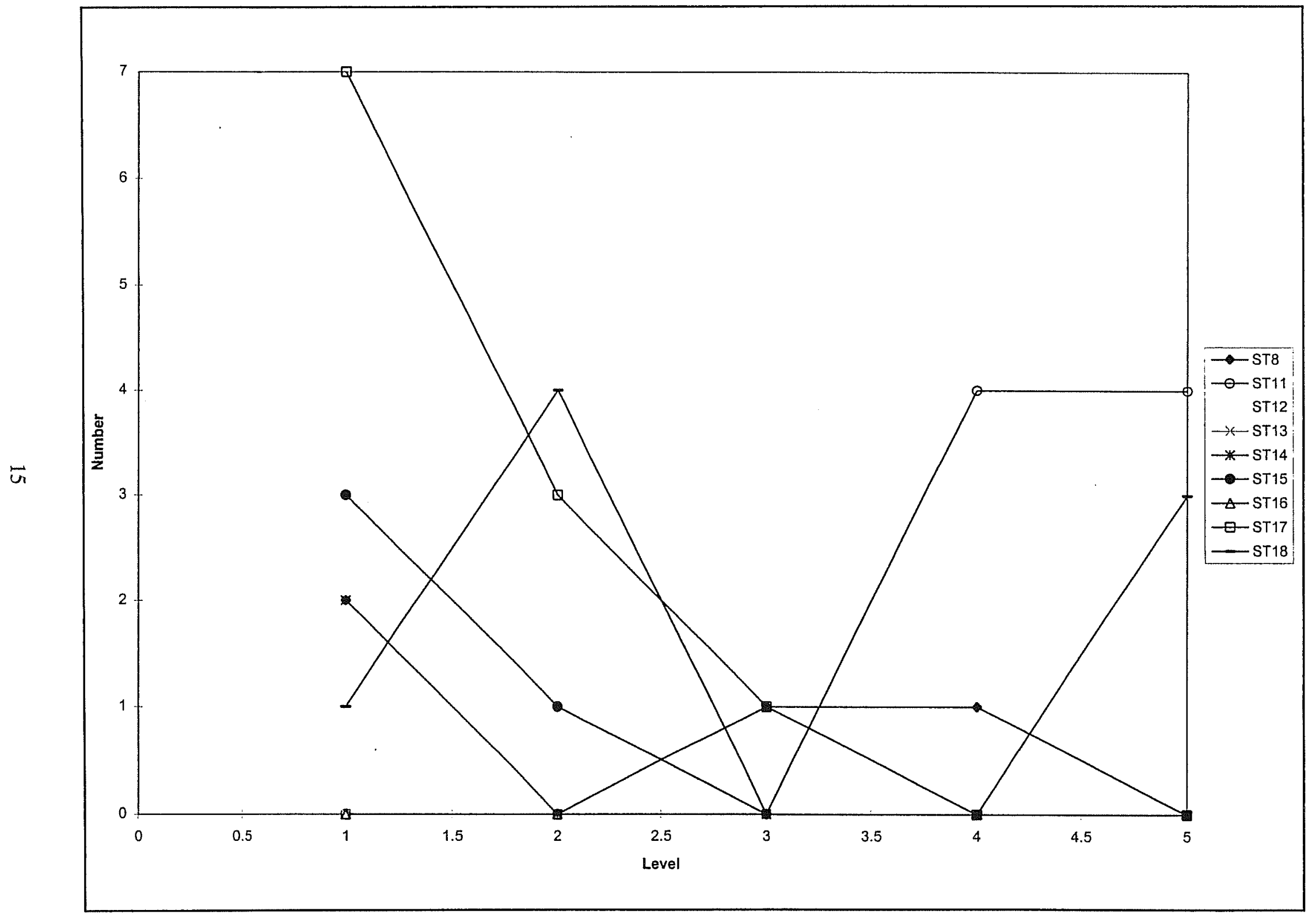

Figure 8. Total prehistoric artifact counts by level for STs $8,11,12,13,14,15,16,17$, and 18 . 
Shovel Tests 19-23

Five shovel tests (ST 19-23) were excavated adjacent to the western edge of the parking lot curb in the location where the city of San Marcos is proposing the construction of a sidewalk (Figure 3). The top surface of these shovel tests was previously graded by a bulldozer. Each shovel test was excavated to a depth level with the parking lot grade ( $40 \mathrm{~cm}$ bs for STs 19,20 , and 22; and $20 \mathrm{~cm}$ bs for ST 23), except ST 21 which was excavated to $60 \mathrm{~cm}$ bs.

Within STs 19-22, the soil in the upper levelsfrom the surface to $20 \mathrm{~cm}$ bs-consisted of a dark greyish brown clay loam mixed with a $\tan$ or yellowish red matrix and gravels ( $A B$ horizon). Below $20 \mathrm{~cm} \mathrm{bs}$, the soil changed to a solid yellowish red clay loam (B horizon). Within the B horizon, from $25-35 \mathrm{~cm}$ bs, a snail shell fragment zone was located within all but ST 23. Prehistoric remains were found in STs 19-22 (Appendix and Figure 9). Modern debris was found only in ST 20 within the top $10 \mathrm{~cm}$ bs. In all five shovel tests, the geological deposits and archaeological materials appear intact.

\section{Test Units}

\section{Test Unit 1}

TU 1 was located southwest of the city's backhoe trench and was excavated to a depth of $50 \mathrm{~cm}$ bs (Figure 3). The stratigraphy of the test unit included an A horizon consisting of a dark grey clay loam with gravel and roots from the surface to $10 \mathrm{~cm}$ bs. The A horizon continued from 10-20 $\mathrm{cm}$ bs with roots and less gravel. A gradual soil change to the transitional $\mathrm{AB}$ horizon occurs at 20-30 cm bs, and a definite soil change to a yellowish-red clay loam (B horizon) at $30 \mathrm{~cm}$ bs. At approximately $40 \mathrm{~cm}$ bs, Rabdotus snail shell appear within the $\mathrm{B}$ horizon. The $\mathrm{B}$ horizon continued to $50 \mathrm{~cm}$ bs where the excavation of TU 1 was terminated.

Historic artifacts and/or modern debris were present only in the first three levels. Historic materials included late-nineteenth- to early twentieth-century stoneware and ironstone ceramics, a clear glass button, glass fragments, and nails. Prehistoric archaeological remains were recovered from every level within TU 1 (Appendix). Figure 10 illustrates the total number of prehistoric remains, burned rock, and historic material recovered from each level within TU 1.

Two prehistoric material peaks are apparent. The numbers of prehistoric remains increase dramatically between 10 and $25 \mathrm{~cm}$ bs and decrease between 25 and $40 \mathrm{~cm}$ bs, and increase again between 40 and $50 \mathrm{~cm}$ bs. Burned-rock remains peak at $30 \mathrm{~cm}$ bs.

Prehistoric material within the $10-30-\mathrm{cm}$-bs levels includes 283 debitage pieces ( 74 platform and 209 non-platform flakes), 1 uniface (an oval scraper), 2 projectile points ( 1 distal end of a point and 1 complete unidentifiable point found at $15 \mathrm{~cm}$ bs [Figure 5d]), and 6 ground stone fragments of ferruginous sandstone. Ground ferruginous sandstone was recently identified at a similar site in Landa Park, New Braunfels, Texas, and was reported to have been possibly transported to the site from about $40-50 \mathrm{~km}$ to the east (Arnn 1997:6).

Ferruginous sandstones do not occur locally, but they exist about $35-40 \mathrm{~km}$ east and south of San Marcos. The formations consists of a band of Eocene sandstone (Carrizo Sands) extending from Frio County north and east through the state, interrupted only by major river drainages (Barnes 1979; Fisher 1985). Charcoal fragments and 122 burned rock pieces (i.e. caliche, chert, limestone, and sandstone) were recovered from Levels 2 and 3 as well. Located in the northeastern quadrant of TU 1, a cluster of approximately 15 small burned limestone rocks $(5 \mathrm{~cm}$ in diameter), was designated Feature 1. This feature extends from 26 to $30 \mathrm{~cm}$ bs and is roughly $25 \times 30 \mathrm{~cm}$ in plan view (Figure 11). Both geological deposits and archaeological materials are intact within TU 1 from $30 \mathrm{~cm}$ bs to $50 \mathrm{~cm}$ bs. 


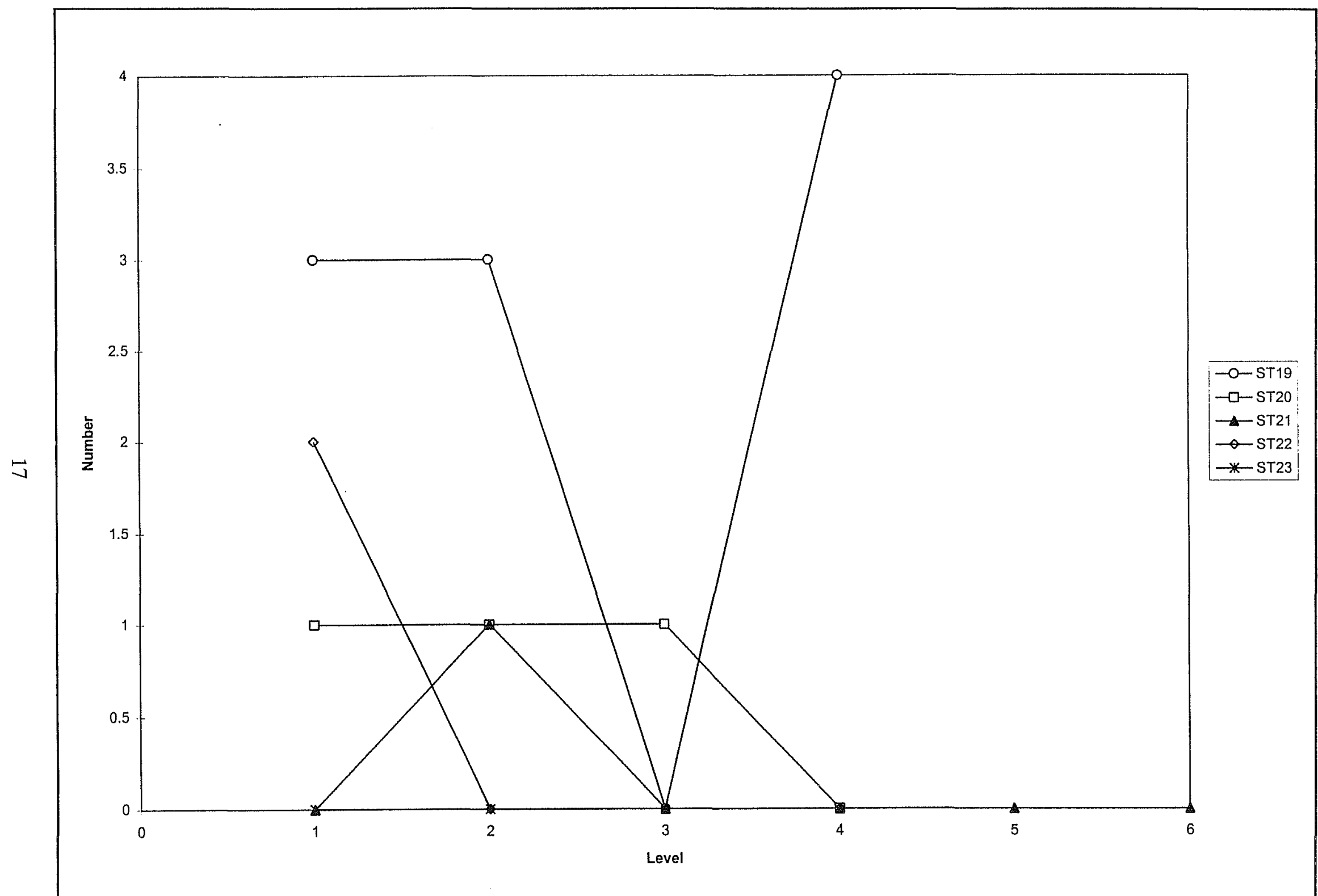

Figure 9. Total prehistoric artifacts counts by level for PTs 19,20,21, 22, and 23. 


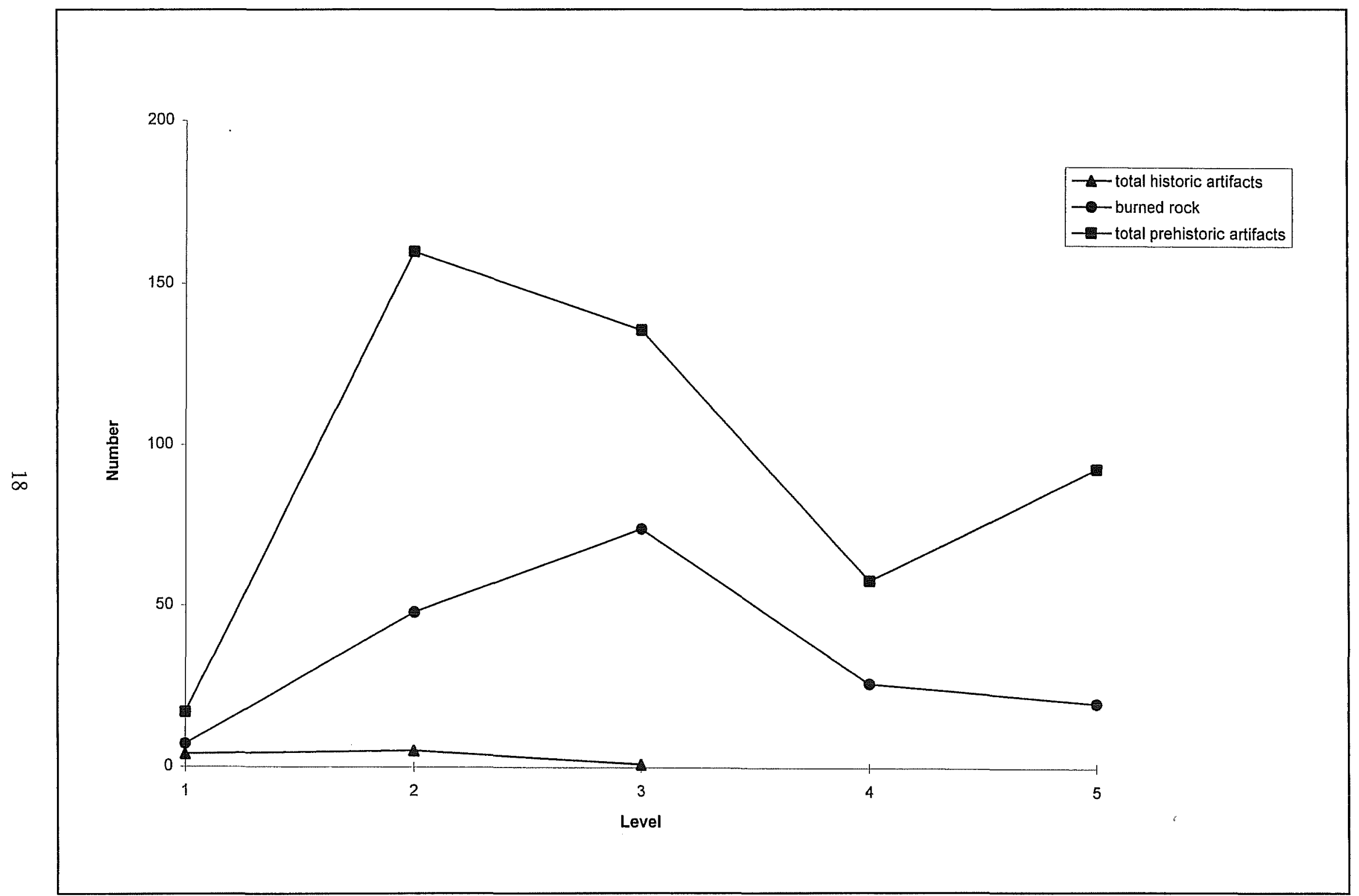

Figure 10. Total prehistoric artifact, burned rock, and historic artifact counts by level, TU 1 . 


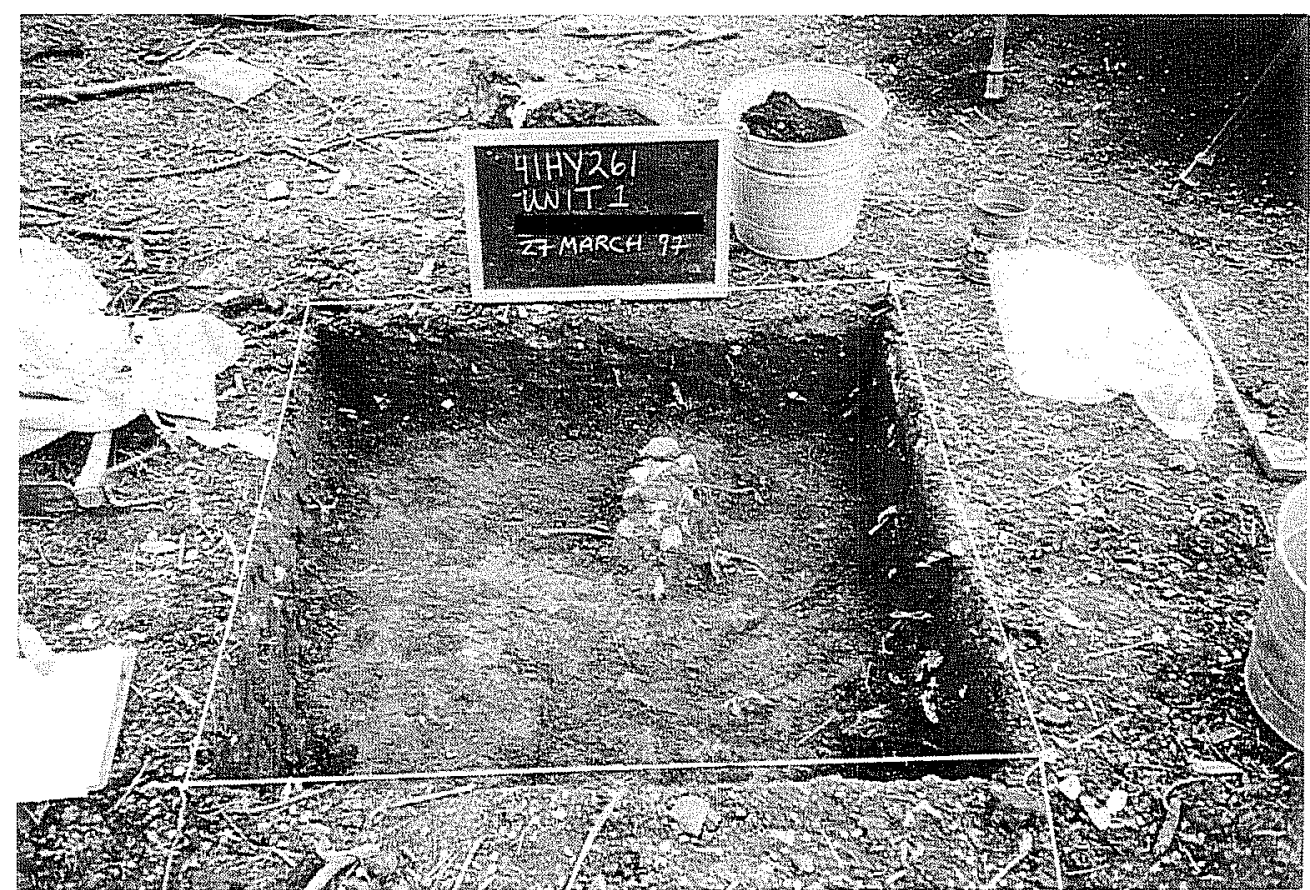

Figure 11. Test Unit 1, Feature 1.

in the Appendix. Figure 12 illustrates, by level, the total number of prehistoric remains, burned rock, and historic artifacts found in TU 2.

Historic remains and/or modern debris were found within the top six levels (to $60 \mathrm{~cm}$ ). This included modern glass and metal, historic ceramics (ironstone, stoneware, and whiteware sherds), window and bottle glass,

\section{Test Unit 2}

TU 2 was located within the eastern end of the city's backhoe trench and was excavated to a depth of $150 \mathrm{~cm}$ bs (Figures 3 and 4). The geological make-up of TU 2 includes fill, from the surface to approximately $20 \mathrm{~cm}$ bs, consisting of a dark brown loam gravel and caliche limestone gravel (AP1 and AP2 zones); an A horizon with tree roots and an abundance of cultural material from about $20-45 \mathrm{~cm}$ bs; a transitional $A B$ horizon with less cultural material from approximately $45-75 \mathrm{~cm}$ bs; and a B horizon from $75-150 \mathrm{~cm}$ (where the test unit was terminated). Within the B horizon two distinct bands of snail shell (Helicina, Polygyra, and Rabdotus) fragment inclusions were observed.

One shell band occurred at the top of the B horizon from about 75-95 cm bs, and the other from about $120-150 \mathrm{~cm}$ bs. The latter was more concentrated in clusters and, for the first time, calcium carbonate was present on many of the cultural remains recovered from these levels. The total numbers of prehistoric and historic artifacts recovered from each level within TU 2 are shown and round nails. Most of the historic remains were concentrated within the top $40 \mathrm{~cm}$ bs, although one piece of wire was found from $40-50 \mathrm{~cm}$ bs and one ironstone sherd was recovered from the $50-60 \mathrm{~cm}$ bs level.

Prehistoric remains were recovered from the surface to the bottom at $150 \mathrm{~cm}$ bs within TU 2 . Figure 12 illustrates two large peaks and one small peak which represent increases in the total numbers of prehistoric artifacts. Prehistoric remains increase dramatically from $30-40 \mathrm{~cm}$ bs, decrease from $40-80 \mathrm{~cm}$ bs, increase in even greater numbers from $80-100 \mathrm{~cm}$ bs, decrease from $100-120 \mathrm{~cm} \mathrm{bs}$, and increase slightly from $120-140 \mathrm{~cm}$ bs. Burned rock increases slightly three times as well, and is represented by three small peaks, as shown in Figure 12. The burned rock peaks occur from $30-40 \mathrm{~cm}$ bs, from $60-70$ $\mathrm{cm}$ bs, and from 120-140 cm.

Prehistoric remains from $30-40 \mathrm{~cm}$ bs include debitage (65 platform flakes and 126 non-platform flakes); 2 cores; and tools ( 2 unifaces, 1 biface, 1 complete projectile point, 1 proximal end, and 2 distal ends of projectile points). Diagnostic 


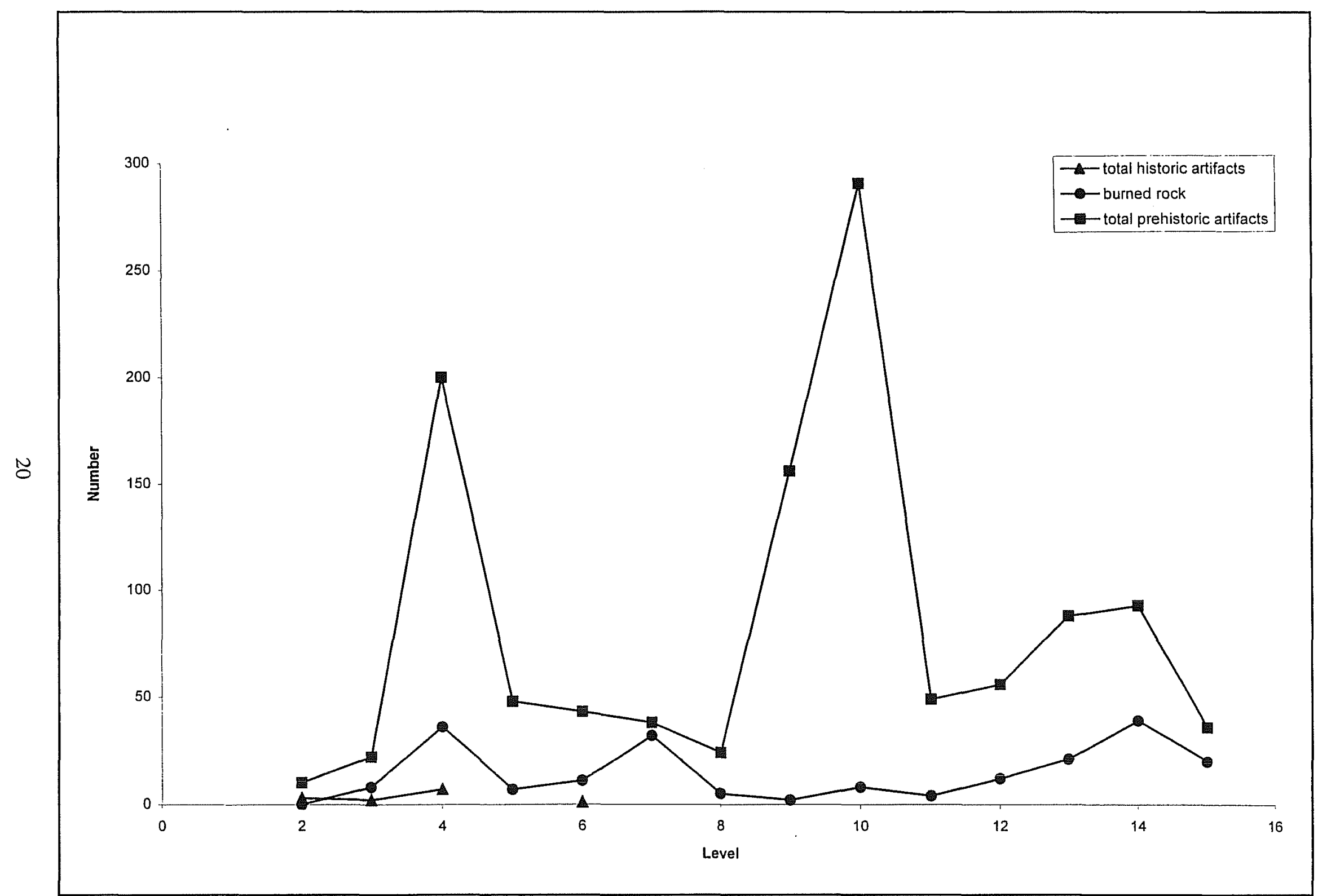

Figure 12. Total prehistoric artifact, burned rock, and historic artifact counts by level, TU 2. 
projectile points from this level include a complete Late Archaic Ensor, ca. 2150-1350 B.P. (Turner and Hester 1993:114), and the proximal end of a Late Archaic Castroville, ca. 2750-2350 B.P. (Turner and Hester 1993:86) (Figures 5e and 5f). One other diagnostic projectile point-the proximal end of a Middle Archaic Marshall, ca. 2950 B.P. or earlier (Turner and Hester 1993:149) (Figure 5g)-was recovered from $40-50 \mathrm{~cm}$ bs. The second and larger peak of prehistoric remains from $80-100 \mathrm{~cm}$ bs is represented by very small chert debitage. A total of 446 pieces of debitage (123 platform flakes and 323 non-platform flakes) and no tools were found within these two levels. A slight increase in the amount of debitage, tools, burned rock, and charcoal is seen within the last peak from 120-140 cm bs (Figure 12).

\section{Summary of Test Units 1 and 2}

Both test units exhibit similar patterns of vertical artifact distribution (Figures 10 and 12). The first artifact peak occurs within the A horizon where there appears to be turbation resulting in a mixed assemblage of modern and historic artifacts with a large prehistoric component. This occurs from $10-20 \mathrm{~cm}$ bs in TU 1 and from $30-40 \mathrm{~cm}$ bs in TU 2. In TU 2, limited mixing extending into the transitional $\mathrm{AB}$ horizon from $50-60 \mathrm{~cm}$ bs is observed. This mixing is marked by the presence of an ironstone ceramic sherd and a piece of wire mixed with the prehistoric assemblage.

A second prehistoric artifact peak occurs within both test units within the $\mathrm{B}$ horizon. This occurs from $40-50 \mathrm{~cm}$ bs in TU 1 and from $80-100 \mathrm{~cm}$ bs in TU 2. Intact geological deposits and cultural materials occur within the B horizon in both TU 1 and TU 2. In TU 1 , this is observed between 30 and $50 \mathrm{~cm}$ bs (TU 1 terminated at 50 $\mathrm{cm} \mathrm{bs}$ ) and in TU 2, between 60 and $150 \mathrm{~cm}$ bs (TU 2 terminated at $150 \mathrm{~cm} \mathrm{bs}$ ).

\section{Unprovenienced Artifacts}

Dr. Thomas R. Hester of the Texas Archaeological Research Laboratory at The
University of Texas at Austin and Mark Denton of the Texas Historic Commission independently provided small collections of artifacts from $41 \mathrm{HY} 261$ to CAR. These artifacts were classified as unknown provenience material (Figure 13). Some pieces are reputed to have come from the parking lot as it was being excavated by the city of San Marcos. The artifacts include both prehistoric remains in the form of points, bifaces, scrapers, and debitage, and Historic glass fragments and one ceramic sherd (Appendix). The latter is an ironstone plate fragment with a Clementson Bros. maker's mark, dating to ca. 1867-1880 (Godden 1964:149). These remains provide important chronological information about the site. The diagnostic lithics include an Early Archaic period Early Triangular point (ca. 5650-5550 B.P., Figure 13a), a Middle Archaic Pedernales point (ca. 3950-3150 B.P., Figure 13b), a Late Archaic Castroville point (ca. 2750-2350 B.P., Figure 13c), and a Late Prehistoric Scallorn point (ca. 1250-750 B.P., Figure 13d) (Turner and Hester 1993). The diagnostic lithic artifacts include several points ranging from the Early Archaic to the Late Prehistoric, suggesting the site was occupied by different people at different periods for over 5,000 years.

\section{Summary and Recommendations}

Archaeological testing demonstrates that site 41HY261 contains deep, intact, cultural deposits represented by a large number of lithic artifacts. The actual vertical depth of cultural material is unknown due to the termination of TU 2 at 150 $\mathrm{cm}$ bs (this last level continued to yield artifacts). Intact geological deposits and prehistoric cultural remains occur within the B soil horizon in both TU 1 and 2. Based on shovel tests randomly placed across the project area, the southern and eastern horizontal extent of $41 \mathrm{HY} 261$ terminates in the area of STs 15 and 16 (Figure 3). This enlarges the original 1994 site boundary south toward $\mathrm{IH}-35$, and the site probably extends even further. Subsurface disturbances observed to a depth of $40-50 \mathrm{~cm}$ bs in STs 17 and 18 


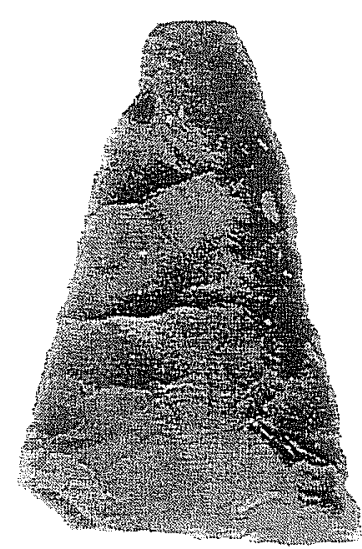

a

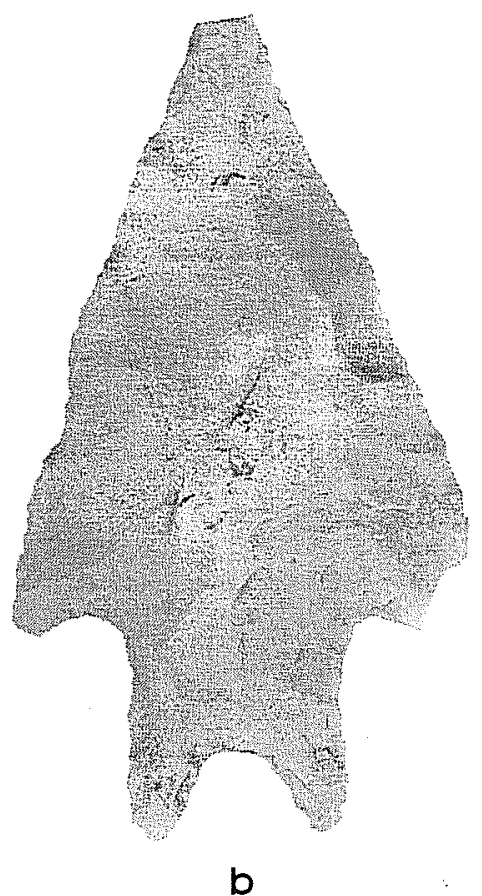

b

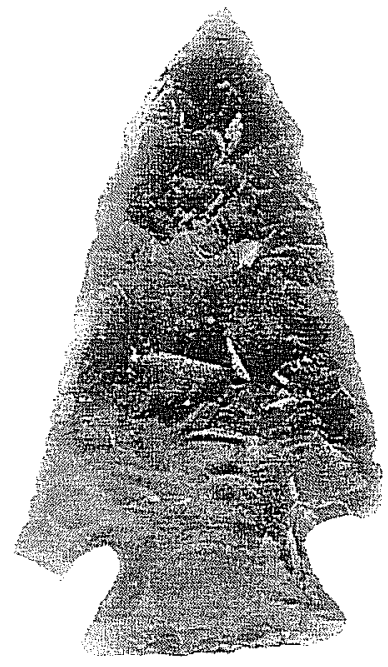

C

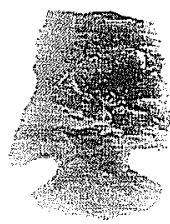

d

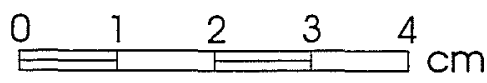

Figure 13. Unprovenienced projectile points. a. Early Triangular; b. Pedernales; c. Castroville.; d. Scallorn.

(south of STs 15 and 16) demonstrate that these shovel tests may not provide accurate information regarding site boundaries.

Within the site boundaries, the depth of subsurface disturbance varies between 10 and 60 $\mathrm{cm}$ bs. This reflects the numerous and varied activities which have occurred at $41 \mathrm{HY} 261$. Areas depicted as "fill" in Figure 2 contain cultural material removed from its original context (parking lot area). Shovel tests placed within fill areas demonstrate that the deposit consists of either a dark brown (A horizon) or a mixed $\mathrm{A}$ and $B$ soil horizon matrix, approximately $20 \mathrm{~cm}$ deep, containing prehistoric, historic, and modern materials. In two of the three shovel tests located within the fill areas (STs 14 and 18), cultural material was not observed below the $20-\mathrm{cm}$ fill deposit, while the third shovel test (ST 15) contained a single piece of burned chert at $40 \mathrm{~cm}$ bs. Shovel tests adjacent to the fill areas (STs 8, 11 , and 17) demonstrate subsurface disturbance to a depth of $40-50 \mathrm{~cm}$ bs. These shovel tests contain a mix of prehistoric, historic, and modern materials. Much of this subsurface disturbance is apparently associated with the construction of the trailer park and gas station. Similarly, subsurface mixing in the A soil horizon (presence of modern materials) is observed in STs $1,2,3$, and 7 in the north and western part of the site. Shovel tests 12 , 13 , and 23 were void of prehistoric cultural material. 
In sum, it is not possible to use artifactual data to differentiate displaced artifacts associated with parking lot fill from legitimate (disturbed) prehistoric deposits as both contexts are represented by a mix of modern, historic, and prehistoric materials in the A horizon. Generally speaking, artifacts originating from the construction of the parking lot are presently restricted to the upper $20 \mathrm{~cm}$ of soil in the fill areas. However, these artifacts will in time, no doubt, move downward with the shrinking and swelling of the clay. Despite past and modern impacts to $41 \mathrm{HY} 261$, certain areas are intact within the A horizon (demonstrated by STs $4 \mathrm{a}$, $5 a, 6,9,10,15$, and 16), and site integrity is well preserved within the B horizon (TUs 1 and 2, and STs 3, 4, 5a, 6, 7, 9, and 10). Future evaluations of the park therefore, should take into account the presence of both intact and disturbed prehistoric deposits.

Two peaks in lithic density are observed at similar levels in TUs 1 and 2 (Figures 10 and 12). This occurs once within the A horizon, and once within the $\mathrm{B}$ horizon. In addition, TU 2 exhibits a third, smaller peak in lithic density at $120-140 \mathrm{~cm}$ bs, and two peaks in burned rock density correspond with the first and third peaks in lithic density. This suggests an increase in the utilization of the site during three different periods of time. A peak in burned rock density also occurs at $30 \mathrm{~cm}$ bs in TU 1 and $60-70 \mathrm{~cm}$ bs in TU 2 .

Two diagnostic projectile points recovered from TU 2-a Transitional Archaic Ensor (30-40 cm bs) and a Middle Archaic Marshall (40-50 cm bs)-indicate that $41 \mathrm{HY} 261$ may contain prehistoric occupations which are separated stratigraphically. In addition, the presence of organic materials such as bone, shell, and charcoal demonstrates that preservation is good. Based on point typology (Early Triangular, Pedernales, Marshall, Castroville, Ensor, Fairiand, and Scallorn), site 41HY261 reflects prehistoric hunter-and-gatherer activity from the Early Archaic to the Late Prehistoric periods.
Generally speaking, within the A horizon the least disturbed part of the site is south of the city's backhoe trench, extending into the area with STs 9 and 10. Additional work is therefore recommended in areas associated with TU 1 and STs $6,7,9$, and 10 (Figure 14). The presence of looters' holes must be considered prior to further archaeological investigation. Located on an upland terrace overlooking the San Marcos River, portions of $41 \mathrm{HY} 261$ are represented by deep, intact, and stratified subsurface cultural deposits. Collectively, the artifacts reflect ca. 5,000 years of activity by prehistoric hunters and gatherers. Therefore, $41 \mathrm{HY} 261$ has the potential to contribute significantly to the prehistory of the region and is recommended as eligible for nomination to the National Register of Historic Places. 


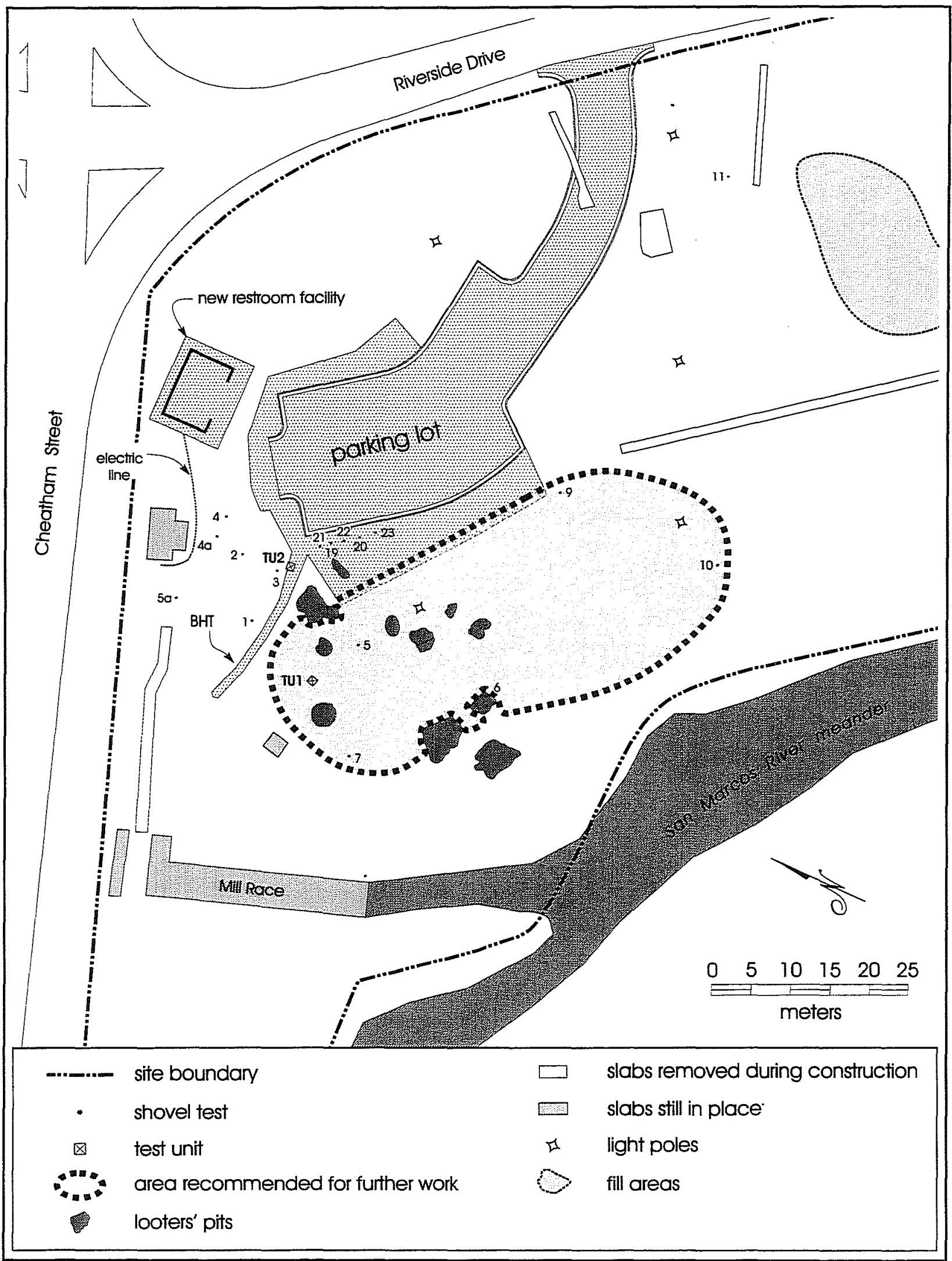

Figure 14. Area designated for further investigations. 


\section{References Cited}

Arnn, J. W., III

1997 Archaeological Investigations at the Landa Park Golf Course, New Braunfels, Texas. Archaeological Survey Report, No. 250. Center for Archaeological Research, The University of Texas at San Antonio.

Bannon, J. F.

1979 The Spanish Borderlands Frontier 1513-1821. University of New Mexico Press, Albuquerque.

Batte, C. D.

1984 Soil Survey of Comal and Hays Counties, Texas. Soil Conservation Service, Temple, Texas.

Barnes, V.

1979 Geologic Atlas of Texas. Seguin Sheet. Bureau of Economic Geology, The University of Texas at Austin.

Black, S. L.

1989a Environmental Setting. In From the Gulf Coast to the Rio Grande: Human Adaptation in the Central, South, and Lower Pecos Texas, edited by T. R. Hester, S. L. Black, D. G. Steele, B. W. Olive, A. A. Fox, K. J. Reinhard, and L. C. Bement, pp. 5-17. Research Series No. 33. Arkansas Archeological Survey, Fayetteville.

1989b Central Texas Plateau Prairie. In From the Gulf Coast to the Rio Grande: Human Adaptation in Central, South and Lower Pecos Texas, edited by T. R. Hester, S. L. Black, D. G. Steele, B. W. Olive, A. A. Fox, K. J. Reinhard, and L. C. Bement, pp. 17-38. Research Series No. 33. Arkansas Archeological Survey, Fayetteville.

1989c South Texas Plain. In From the Gulf Coast to the Rio Grande: Human Adaptation in the Central, South, and Lower Pecos Texas, edited by T. R. Hester, S. L. Black, D. G. Steele, B. W. Olive, A. A. Fox, K. J. Reinhard, and L. C. Bement, pp. 39-62. Research Series No. 33. Arkansas Archaeological Survey, Fayetteville.

Black, S. L., L. W. Ellis, D. G. Creel, and G. T. Goode

1996 Hot Rock Cooking on the Greater Edwards Plateau: Four Burned Rock Midden Sites in West Central Texas. Studies in Archeology. Texas Archeological Research Laboratory, The University of Texas at Austin. Review draft.

Blair, W. F.

1950 The Biotic Provinces of Texas. The Texas Journal of Science 2(1):93-117.

Bomar, G. W.

1983 Texas Weather. University of Texas Press, Austin.

Bruseth, J. E.

1992 Artifacts of the De Soto Expedition: The Evidence from Texas. Bulletin of the Texas Archeological Society 63:67-97. 
Collins, M. B.

1995 Forty Years of Archeology in Central Texas. Bulletin of the Texas Archeological Society $66: 361-400$.

Collins, M. B., and R. A. Ricklis

1994 Cultural Background. In Archaic and Late Prehistoric Human Ecology in the Middle Onion Creek Valley, Hays County, Texas, edited by M. B. Collins and R. A. Ricklis, 1:11-26. Studies in Archeology 19. Texas Archeological Research Laboratory, The University of Texas at Austin.

Fisher, W. L.

1985 The Guadalupe-Lavaca-San Antonio-Nueces River Basins Regional Study, Physical Materials, Austin-West, Seguin-West Sheets, Texas, Plate 2. Bureau of Economic Geology, The University of Texas at Austin.

Godden, G. A.

1964 Encyclopedia of British Pottery and Porcelain Marks. Bonanza, New York.

McCulloch, S. D., and M. W. Voellinger

1996 Cultural Resources Investigation of the Henry Tract, San Marcos, Hays County, Texas. Environmental Archeology Series 10. S. A. Garza Engineers, Austin.

McKinney, W. W.

1981 Early Holocene Adaptations in Central and Southwestern Texas: The Problem of the PaleoindianArchaic Transition. In Bulletin of the Texas Archeological Society 52:91-120.

Ricklis, R. A.

1994 Toyah Components: Evidence For Occupation in the Project Area During the Latter Part of the Late Prehistoric Period. In Archaic and Late Prehistoric Human Ecology in the Middle Onion Creek Valley, Hays County, Texas, edited by M. B. Collins and R. A. Ricklis, 1:207-315. Studies in Archeology 19. Texas Archeological Research Laboratory, The University of Texas at Austin.

Ricklis, R. A., and M. B. Collins

1994 The Environmental Context. In Archaic and Late Prehistoric Human Ecology in the Middle Onion Creek Valley, Hays County, Texas, edited by M. B. Collins and R. A. Ricklis, 1:27-36. Studies in Archeology 19. Texas Archeological Research Laboratory, The University of Texas at Austin.

Tennis, C. L.

1996 Archaic Land Use of Upper Leon Creek Terraces: Archaeological Testing in Northern Bexar County, Texas. Archaeological Survey Report, No. 234. Center for Archaeological Research, The University of Texas at San Antonio.

Trierweiler, W. N., G. L. Ellis, and J. M. Quigg

1995 Research Context for Site Testing. In NRHP Significance Testing of 57 Prehistoric Archaeological Sites on Fort Hood, Texas. Archaeological Resource Management Series Research Report No. 34. Vol 1:27-38. United States Army, Fort Hood. 
Turner, E. S., and T. R. Hester

1993 A Field Guide to Stone Artifacts of Texas Indians. Gulf, Houston.

Weir, F. A.

1976 The Central Texas Archaic. Unpublished Ph.D. dissertation. Washington State University, Pullman. 
Appendix: Artifact Data

\begin{tabular}{|c|c|c|c|c|c|c|c|c|c|c|c|c|c|c|c|c|}
\hline \multirow{2}{*}{\multicolumn{2}{|c|}{ Provenience }} & \multicolumn{10}{|c|}{ Prehistoric } & \multirow{2}{*}{\multicolumn{4}{|c|}{ Historic }} & \multirow[b]{3}{*}{ 营 } \\
\hline & & \multicolumn{3}{|c|}{ Waste } & \multicolumn{4}{|c|}{ Tools } & \multicolumn{2}{|c|}{ Faunal } & \multirow[b]{2}{*}{ 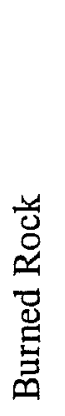 } & & & & & \\
\hline 峊 & 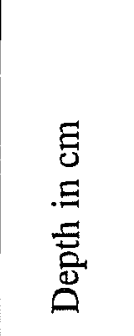 & 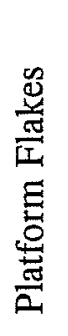 & 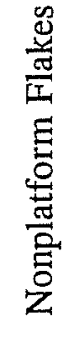 & ن் & 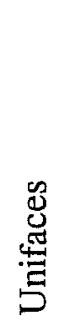 & 总 & : & 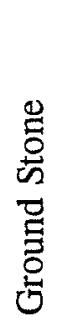 & $\stackrel{\mathscr{B}}{\circ}$ & $\frac{\bar{g}}{\bar{\sigma}}$ & & 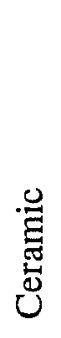 & $\underset{\substack{0 \\
0}}{\stackrel{0}{0}}$ & $\sum_{\Sigma}^{\bar{d}}$ & $\stackrel{\vec{D}}{\tilde{D}}$ & \\
\hline TU 1 & $0-10$ & 2 & 14 & & & & & & 4 & & 7 & 2 & & 1 & 1 & 31 \\
\hline TU 1 & $10-20$ & 29 & 123 & 1 & 4 & & 2 & 2 & 11 & & 48 & 4 & & 1 & & 225 \\
\hline TU 1 & $20-30$ & 45 & 86 & & 1 & & & 4 & & & 74 & & 1 & & & 211 \\
\hline TU 1 & $30-40$ & 13 & 44 & 1 & & & & & & & 26 & & & & & 84 \\
\hline TU 1 & $40-50$ & 22 & 69 & 1 & & 1 & & & 4 & & 20 & & & & & 117 \\
\hline TU 2 & $0-20$ & 3 & 7 & & & & & & & & & 2 & & 1 & & 13 \\
\hline TU 2 & $20-30$ & 10 & 12 & & & & & & 6 & & 8 & 1 & & 1 & & 38 \\
\hline TU 2 & $30-40$ & 65 & 126 & 2 & 2 & 1 & 4 & & 10 & & 36 & & 4 & 3 & & 253 \\
\hline TU 2 & $40-50$ & 21 & 23 & & 2 & 1 & 1 & & 21 & & 7 & & & & & 76 \\
\hline TU 2 & $50-60$ & 21 & 18 & & 2 & 1 & 1 & & 1 & & 11 & 1 & & & & 56 \\
\hline TU 2 & $60-70$ & 14 & 23 & & 1 & & & & & & 32 & & & & & 70 \\
\hline TU 2 & $70-80$ & 11 & 11 & & 1 & 1 & & & & & 5 & & & & & 29 \\
\hline TU 2 & $80-90$ & 49 & 106 & & 1 & & & & & & 2 & & & & & 158 \\
\hline TU 2 & $90-100$ & 74 & 217 & & & & & & 2 & & 8 & & & & & 301 \\
\hline TU 2 & $100-110$ & 20 & 29 & & & & & & 3 & & 4 & & & & & 56 \\
\hline TU 2 & $110-120$ & 16 & 38 & & 1 & 1 & & & 1 & 4 & 12 & & & & & 73 \\
\hline TU 2 & $120-130$ & 28 & 60 & & & & & & & & 21 & & & & & 109 \\
\hline TU 2 & $130-140$ & 37 & 56 & & & & & & 1 & & 39 & & & & & 133 \\
\hline TU 2 & $140-150$ & 17 & 17 & & & 2 & & & 2 & & 20 & & & & & 58 \\
\hline ST 1 & $0-10$ & & 1 & & & & & & & & & & & & & 1 \\
\hline ST 1 & $10-20$ & 1 & 1 & & & & & & 2 & & & & & & & 4 \\
\hline ST 1 & $20-30$ & & 20 & & 2 & & & & 1 & & & & & 1 & & 24 \\
\hline ST 1 & $30-40$ & 3 & 11 & & 1 & & & & 4 & & 8 & & & & & 27 \\
\hline ST 1 & $40-50$ & & 3 & & & & & & 1 & & & & & & & 4 \\
\hline ST 1 & $50-60$ & 1 & 4 & & & & & & 3 & & 1 & & & 1 & & 10 \\
\hline ST 2 & $0-10$ & & 4 & & 1 & & & & 1 & & & & & & & 6 \\
\hline ST 2 & $10-20$ & & 3 & & & & & & 1 & & & 2 & & & & 6 \\
\hline ST 2 & $20-30$ & & 1 & & & & & & & & 1 & 2 & & 2 & & 6 \\
\hline
\end{tabular}




\begin{tabular}{|c|c|c|c|c|c|c|c|c|c|c|c|c|c|c|c|c|}
\hline \multirow{2}{*}{\multicolumn{2}{|c|}{ Provenience }} & \multicolumn{10}{|c|}{ Prehistoric } & \multirow{2}{*}{\multicolumn{4}{|c|}{ Historic }} & \multirow[b]{3}{*}{$\stackrel{\frac{0}{\pi}}{\frac{\pi}{0}}$} \\
\hline & & \multicolumn{3}{|c|}{ Waste } & \multicolumn{4}{|c|}{ Tools } & \multicolumn{2}{|c|}{ Faunal } & \multirow[b]{2}{*}{ 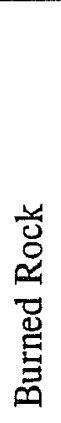 } & & & & & \\
\hline 荣 & 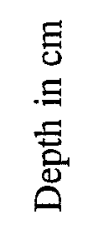 & 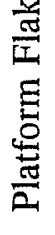 & 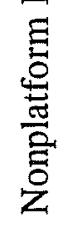 & نัّ & 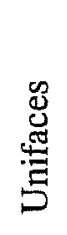 & 岂 & 晜 & 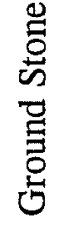 & ஜृ: & $\overline{\bar{\Phi}}$ & & 导总 & $\frac{\mathscr{2}}{0}$ & $\sum^{\frac{\pi}{0}}$ & $\frac{\text { 离 }}{0}$ & \\
\hline ST 2 & $30-40$ & 2 & & & & & & & & & 1 & & & & & 3 \\
\hline ST 2 & $40-50$ & 2 & 4 & & & & & & 1 & & 3 & & & & & 10 \\
\hline ST 2 & $50-60$ & & 1 & & & & & & & & 3 & & 1 & & & 5 \\
\hline ST 3 & $0-10$ & & & & & & & & & & & & & & & 0 \\
\hline ST 3 & $10-20$ & 1 & & & & & & & & & & & & & & 1 \\
\hline ST 3 & $20-30$ & 1 & 1 & & & & & & & & & & & & & 2 \\
\hline ST 3 & $30-40$ & 2 & & & & & & & & & 3 & & & & & 5 \\
\hline ST 3 & $40-50$ & & & & & & & & & & 2 & & & & & 2 \\
\hline ST 3 & $50-60$ & 2 & 2 & & & & & & & & & & & & & 4 \\
\hline ST 4 & $0-10$ & 2 & 1 & & & & & & & & 1 & & 1 & & & 5 \\
\hline ST 4a & $0-10$ & & & & & & & & & & 1 & & & & & 1 \\
\hline ST 4a & $10-20$ & & & & & & & & & & & & & & & 0 \\
\hline ST 4a & $20-30$ & & & & & & & & & & 1 & & & & & 1 \\
\hline ST 4a & $30-40$ & 2 & 4 & & & & & & & & & & & & & 6 \\
\hline ST 4a & $40-50$ & & & & & & & & & & & & & & & 0 \\
\hline ST 4a & $50-60$ & & 1 & & & & & & & & & & & & & 1 \\
\hline ST 4a & $60-70$ & 1 & & & & & & & & & 4 & & & & & 5 \\
\hline ST 5 & $0-10$ & & 3 & 1 & 1 & & & & & & 3 & & & & & 8 \\
\hline ST 5a & $0-10$ & & & & & & & & & & & 1 & & & 1 & 2 \\
\hline ST 5a & $10-20$ & & & & & & & & 2 & & 4 & & & & & 6 \\
\hline ST 5a & $20-30$ & 1 & & 1 & & & & & & & & & & & & 2 \\
\hline ST 5a & $30-40$ & 1 & & & & & & & & & 3 & & & & & 4 \\
\hline ST 5a & $40-50$ & 1 & 1 & & 1 & & & & & & 5 & & & & & 8 \\
\hline ST 5a & $50-60$ & & 1 & 1 & & & & & 1 & & 1 & & & & & 4 \\
\hline ST 6 & $0-10$ & 1 & 3 & & & & & & & & 3 & 1 & & & & 8 \\
\hline ST 6 & $10-20$ & 1 & 2 & & & & & & & & & & & & & 3 \\
\hline ST 6 & $20-30$ & 3 & 8 & 2 & & & & & 1 & & 10 & & & & & 24 \\
\hline ST 6 & $30-40$ & 4 & 7 & & & 1 & & & 1 & & 9 & & & & & 22 \\
\hline ST 6 & $40-50$ & 2 & 1 & & & & & & & & 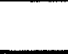 & & & & & 3 \\
\hline ST 6 & $50-60$ & 1 & 2 & & & & & & & & 1 & & & & & 4 \\
\hline ST 7 & $0-10$ & & 6 & & & & 1 & & & & & & & & & 7 \\
\hline ST 7 & $10-20$ & & 3 & & & & & & & & 1 & & & & & 4 \\
\hline
\end{tabular}




\begin{tabular}{|c|c|c|c|c|c|c|c|c|c|c|c|c|c|c|c|c|}
\hline \multirow{2}{*}{\multicolumn{2}{|c|}{ Provenience }} & \multicolumn{10}{|c|}{ Prehistoric } & \multirow{2}{*}{\multicolumn{4}{|c|}{ Historic }} & \\
\hline & & \multicolumn{3}{|c|}{ Waste } & \multicolumn{4}{|c|}{ Tools } & \multicolumn{2}{|c|}{ Faunal } & \multirow[b]{2}{*}{ 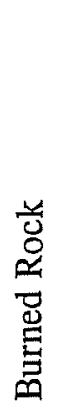 } & & & & & \\
\hline 葛 & 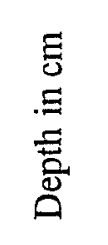 & 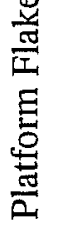 & 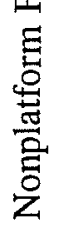 & 造 & 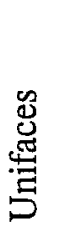 & 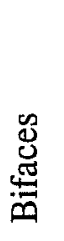 & $\begin{array}{l}\stackrel{0}{\Xi} \\
\stackrel{0}{0} \\
.0\end{array}$ & 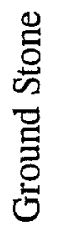 & 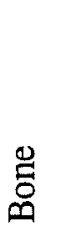 & $\begin{array}{l}\bar{\Phi} \\
\overline{\tilde{n}}\end{array}$ & & 导芯 & $\frac{\mathscr{A}}{\overparen{J}}$ & $\frac{\bar{\pi}}{\sum}$ & $\stackrel{\text { 离 }}{0}$ & $\stackrel{\frac{n}{\pi}}{0}$ \\
\hline ST 7 & $20-30$ & 2 & 2 & & & & & & 1 & & 1 & & & & & 6 \\
\hline ST 7 & $30-40$ & 1 & 3 & & & & & & & & 3 & & & & & 7 \\
\hline ST 7 & $40-50$ & & & & & & & & & & & & & & & 0 \\
\hline ST 7 & $50-60$ & 4 & 6 & & & & & & & & 1 & & & & & 11 \\
\hline ST 8 & $0-10$ & 1 & 1 & & & & & & 3 & & & & 2 & 1 & & 8 \\
\hline ST 8 & $10-20$ & & & & & & & & & & & & & & & 0 \\
\hline ST 8 & $20-30$ & & & 1 & & & & & & & 2 & & & & & 3 \\
\hline ST 8 & $30-40$ & & 1 & & & & & & & & & & & & 1 & 2 \\
\hline ST 8 & $40-50$ & & & & & & & & & & . & & & 1 & 1 & 2 \\
\hline ST 9 & $0-10$ & 2 & 3 & & & & & & & & 1 & & & & & 6 \\
\hline ST 9 & $10-20$ & & 7 & & & & & & & & 2 & & & & & 9 \\
\hline ST 9 & $20-30$ & 2 & 7 & & & & & & & & 1 & & & & & 10 \\
\hline ST 9 & $30-40$ & 1 & 3 & & & & & & & & & & & & & 4 \\
\hline ST 9 & $40-50$ & 1 & 2 & & & & & & & & & & & & & 3 \\
\hline ST 10 & $0-10$ & & & & & & & & & & & & & & & 0 \\
\hline ST 10 & $10-20$ & 1 & 1 & & & & & & & & 1 & & 1 & 1 & & 5 \\
\hline ST 10 & $20-30$ & & 1 & 1 & & & & & & & 4 & & & & & 6 \\
\hline ST 10 & $30-40$ & 1 & & & & 1 & & & 2 & 15 & 13 & & & & & 32 \\
\hline ST 10 & $40-50$ & 2 & 1 & & & & & & & & 4 & & & & & 7 \\
\hline ST 11 & $0-10$ & & & & & & & & & & & & & & & 0 \\
\hline ST 11 & $10-20$ & & & & & & & & & & & & & 3 & & 3 \\
\hline ST 11 & $20-30$ & & & & & & & & & & 1 & & & & & 1 \\
\hline ST 11 & $30-40$ & 1 & 3 & & & & & & & & & & & & & 4 \\
\hline ST 11 & $40-50$ & 1 & 3 & & & & & & & & 1 & & & & & 5 \\
\hline ST 12 & $0-10$ & & & & & & & & & & & & & & & 0 \\
\hline ST 12 & $10-20$ & & & & & & & & & & & & & & & 0 \\
\hline ST 12 & $20-30$ & & & & & & & & & & & & & & 1 & 1 \\
\hline ST 12 & $30-40$ & & & & & & & & & & & 1 & & & & 1 \\
\hline ST 12 & $40-50$ & & & & & & & & & & & & & 1 & & 1 \\
\hline ST 13 & $0-10$ & & & & & & & & & & & & & & & 0 \\
\hline ST 13 & $10-20$ & & & & & & & & & & & & & & & 0 \\
\hline ST 13 & $20-30$ & & & & & & & & & & & & & & & 0 \\
\hline
\end{tabular}




\begin{tabular}{|c|c|c|c|c|c|c|c|c|c|c|c|c|c|c|c|c|}
\hline \multirow{2}{*}{\multicolumn{2}{|c|}{ Provenience }} & \multicolumn{10}{|c|}{ Prehistoric } & \multirow{2}{*}{\multicolumn{4}{|c|}{ Historic }} & \multirow[b]{3}{*}{ 焉 } \\
\hline & & \multicolumn{3}{|c|}{ Waste } & \multicolumn{4}{|c|}{ Tools } & \multicolumn{2}{|c|}{ Faunal } & \multirow[b]{2}{*}{ 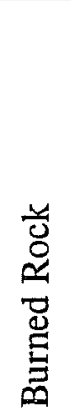 } & & & & & \\
\hline 节 & 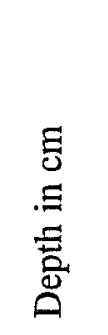 & 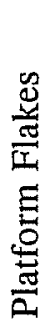 & 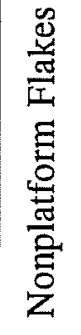 & ن⿺辶ّ & 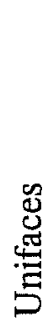 & 岕 & 苛 & 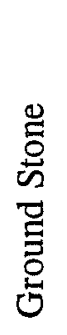 & : & $\overline{\overline{0}}$ & & & 离 & $\sum^{\frac{\pi}{0}}$ & 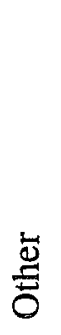 & \\
\hline ST 13 & $30-40$ & & & & & & & & & & & & & & & 0 \\
\hline ST 13 & $40-50$ & & & & & & & & & & & & & & & 0 \\
\hline ST 14 & $0-10$ & & 1 & & 1 & & & & & & 4 & & & & & 6 \\
\hline ST 14 & $10-20$ & & & & & & & & 1 & & 1 & & & & & 2 \\
\hline ST 14 & $20-30$ & & & & & & & & & & & & & & & 0 \\
\hline ST 14 & $30-40$ & & & & & & & & & & & & & & & 0 \\
\hline ST 14 & $40-50$ & & & & & & & & & & & & & & & 0 \\
\hline ST 15 & $0-10$ & 1 & 2 & & & & & & & & 1 & & & & & 4 \\
\hline ST 15 & $10-20$ & & 1 & & & & & & & & & & & 1 & & 2 \\
\hline ST 15 & $20-30$ & & & & & & & & & & & & & & & 0 \\
\hline ST 15 & $30-40$ & & & & & & & & & & 1 & & & & & 1 \\
\hline ST 15 & $40-50$ & & & & & & & & & & & & & & & 0 \\
\hline ST 16 & $0-10$ & & & & & & & & & & & & & & & 0 \\
\hline ST 16 & $10-20$ & & & & & & & & & & & & & & & 0 \\
\hline ST 16 & $20-30$ & & 1 & & & & & & 1 & & & & & & & 2 \\
\hline ST 16 & $30-40$ & & & & & & & & & & & & & & & 0 \\
\hline ST 16 & $40-50$ & & & & & & & & & & & & & & & 0 \\
\hline ST 17 & $0-10$ & 1 & 5 & & & 1 & & & & & & & & 1 & & 8 \\
\hline ST 17 & $10-20$ & & 3 & & & & & & & & & & & & & 3 \\
\hline ST 17 & $20-30$ & & 1 & & & & & & & & 1 & & & 1 & & 3 \\
\hline ST 17 & $30-40$ & & & & & & & & & & & & & & & 0 \\
\hline ST 17 & $40-50$ & & & & & & & & & & 1 & & 2 & & & 3 \\
\hline ST 18 & $0-10$ & & 1 & & & & & & & 1 & 2 & & & & & 4 \\
\hline ST 18 & $10-20$ & & 4 & & & & & & & & 1 & & & & & 5 \\
\hline ST 18 & $20-30$ & & & & & & & & & & & & & & & 0 \\
\hline ST 18 & $30-40$ & & & & & & & & & & & & & & & 0 \\
\hline ST 19 & $0-10$ & 1 & 2 & & & & & & & & 1 & & & & & 4 \\
\hline ST 19 & $10-20$ & & 3 & & & & & & & & & & & & & 3 \\
\hline ST 19 & $20-30$ & & & & & & & & & & & & & & & 0 \\
\hline ST 19 & $30-40$ & 1 & 3 & & & & & & & & & & & & & 4 \\
\hline ST 20 & $0-10$ & & 1 & & & & & & & & 3 & & & & & 4 \\
\hline ST 20 & $10-20$ & & 1 & & & & & & & & & & & & & 1 \\
\hline
\end{tabular}




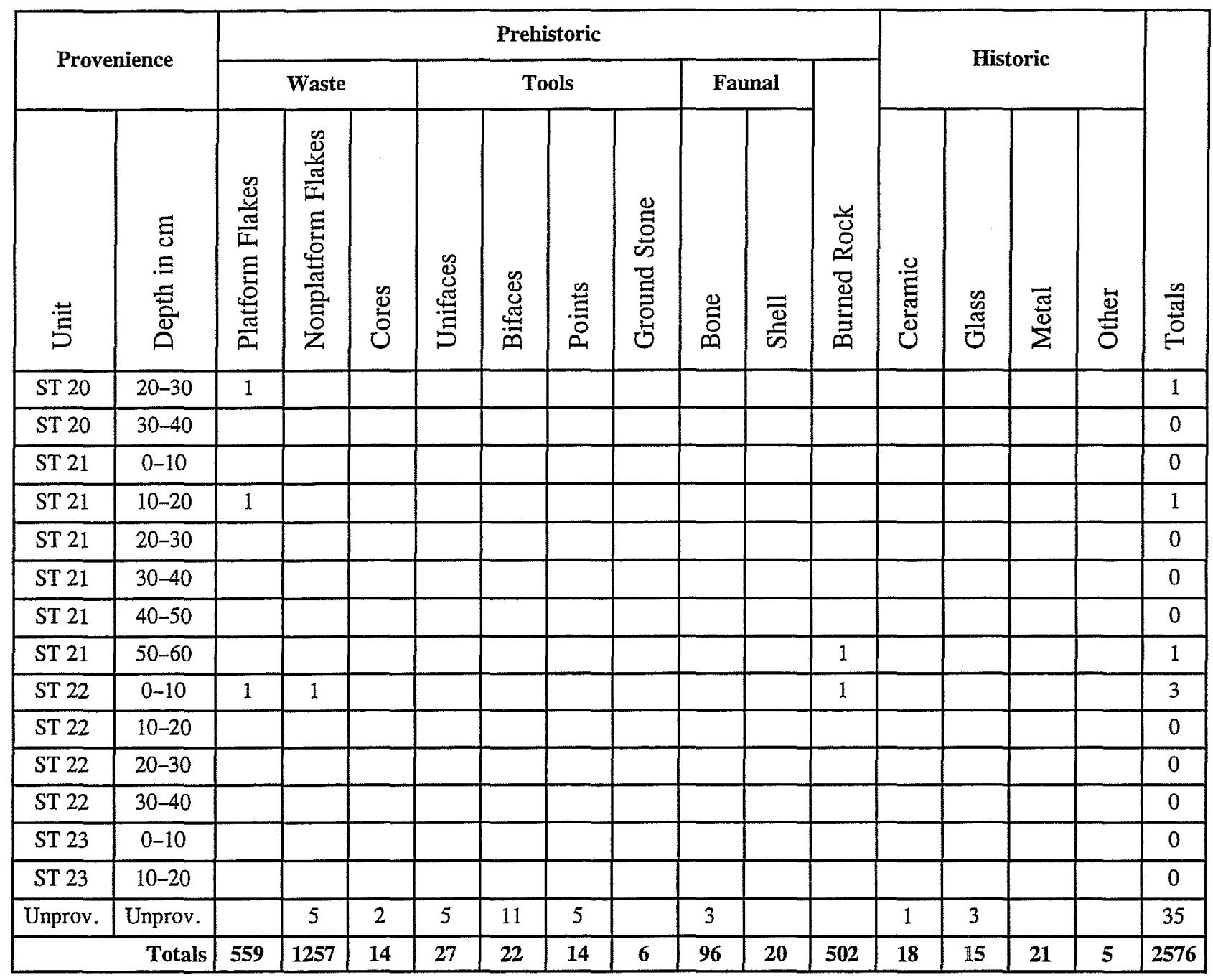

